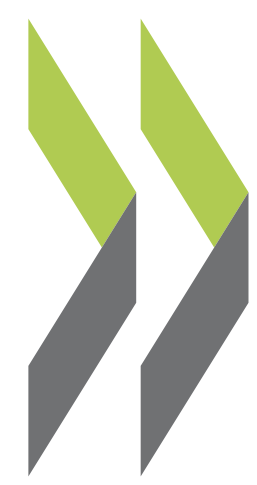

OECD Economics Department Working Papers No. 1358

International tax planning, competition and market structure

Stéphane Sorbe, Asa Johansson 
Organisation de Coopération et de Développement Économiques

Organisation for Economic Co-operation and Development

06-Feb-2017

ECONOMICS DEPARTMENT

English - Or. English

\section{INTERNATIONAL TAX PLANNING, COMPETITION AND MARKET STRUCTURE}

ECONOMICS DEPARTMENTS WORKING PAPERS No. 1358

By Stéphane Sorbe and Åsa Johansson

OECD Working Papers should not be reported as representing the official views of the OECD or of its member countries. The opinions expressed and arguments employed are those of the author(s).

Authorised for publication by Christian Kastrop, Director, Policy Studies Branch, Economics Department.

All Economics Department Working Papers are available at www.oecd.org/eco/workingpapers.

JT03408628

Complete document available on OLIS in its original format

This document and any map included herein are without prejudice to the status of or sovereignty over any territory, to the delimitation of international frontiers and boundaries and to the name of any territory, city or area. 
OECD Working Papers should not be reported as representing the official views of the OECD or of its member countries. The opinions expressed and arguments employed are those of the author(s).

Working Papers describe preliminary results or research in progress by the author(s) and are published to stimulate discussion on a broad range of issues on which the OECD works.

Comments on Working Papers are welcomed, and may be sent to OECD Economics Department, 2 rue André Pascal, 75775 Paris Cedex 16, France, or by e-mail to eco.contact@oecd.org.

All Economics Department Working Papers are available at www.oecd.org/eco/workingpapers.

This document and any map included herein are without prejudice to the status of or sovereignty over any territory, to the delimitation of international frontiers and boundaries and to the name of any territory, city or area.

The statistical data for Israel are supplied by and under the responsibility of the relevant Israeli authorities. The use of such data by the OECD is without prejudice to the status of the Golan Heights, East Jerusalem and Israeli settlements in the West Bank under the terms of international law.

Latvia was not an OECD Member at the time of preparation of this publication. Accordingly, Latvia does not appear in the list of OECD Members and is not included in the zone aggregates.

\section{(c) OECD (2016)}

You can copy, download or print OECD content for your own use, and you can include excerpts from OECD publications, databases and multimedia products in your own documents, presentations, blogs, websites and teaching materials, provided that suitable acknowledgment of OECD as source and copyright owner is given. All requests for commercial use and translation rights should be submitted to rights@oecd.org 


\section{ABSTRACT/RÉSUMÉ}

\section{International tax planning, Competition and market structure}

This paper investigates if tax planning by large multinationals distorts competition in their favour and allows them to crowd out other firms. The competitive implications of tax planning are frequently mentioned in the tax policy debate, but not yet documented empirically to our knowledge. This paper aims to fill this gap. Drawing on firm-level data from the ORBIS database, it compares price-cost mark-up rates of firms with different tax planning opportunities, using several proxy measures of these opportunities, such as links to tax havens. Tax-planning multinationals are found to have higher mark-up rates than other firms, even after controlling for other factors influencing mark-ups. However, the direction of causality is difficult to establish since a high mark-up can be a factor encouraging a firm to engage in tax planning. Based on a new indicator of industry concentration, the empirical analysis also shows that industries with a strong presence of tax-planning multinationals tend to be more concentrated than other industries, but less so when strong rules against tax planning are in place. Overall, the results support the hypothesis that large multinationals use their tax savings to crowd out other firms and ultimately obtain higher mark-ups.

JEL classification codes: D43, F23, H26, L11

Key words: Competition, corporate tax, multinational tax planning

$* * * * * * * * * * * * * * *$

\section{Planification fiscale internationale, concurrence et structure de marché}

Cet article examine si la planification fiscale par les grandes multinationales fausse la concurrence en leur faveur et leur permet d'évincer les autres entreprises. Les implications concurrentielles de la planification fiscale sont fréquemment mentionnées dans le débat sur la politique fiscale, mais pas encore documentées empiriquement à notre connaissance. Cet article vise à combler cette lacune. À partir des données d'entreprise de la base de données ORBIS, il compare les taux de mark-up prix-coûts des entreprises en fonction de leurs opportunités de planification fiscale, en utilisant plusieurs mesures indirectes de ces opportunités, telles que des liens vers des paradis fiscaux. Les multinationales engagées dans la planification fiscale se trouvent avoir des taux de mark-up plus élevés que les autres entreprises, même après ajustement pour d'autres facteurs qui influent sur ces taux. Cependant, la direction de la causalité est difficile à établir car un mark-up élevé peut être un facteur encourageant une entreprise de se livrer à la planification fiscale. Sur la base d'un nouvel indicateur de la concentration de l'industrie, l'analyse empirique montre également que les industries avec une forte présence des multinationales engagées dans la planification fiscale ont tendance à être plus concentrée que d'autres industries, mais que cette différence de concentration est atténuée quand des règles strictes contre la planification fiscale sont en place. Dans l'ensemble, les résultats soutiennent l'hypothèse que les grandes multinationales utilisent leurs économies d'impôt pour évincer d'autres entreprises et, finalement, obtenir des mark-ups plus élevées.

Classification JEL: D43, F23, H26, L11

Mots clés: concurrence, impôts sur les sociétés, planification fiscale internationale 


\section{TABLE OF CONTENTS}

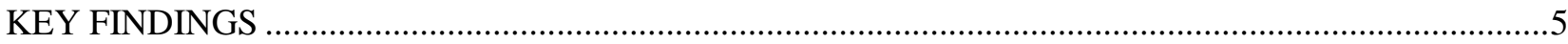

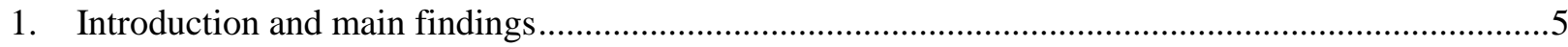

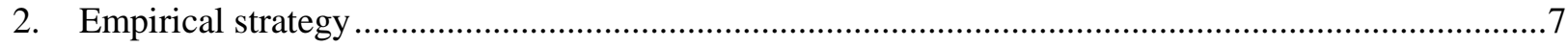

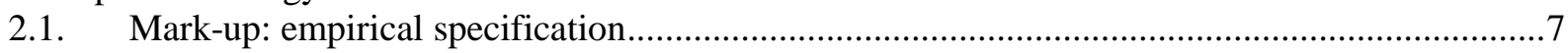

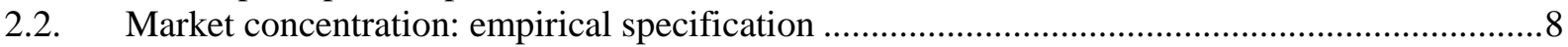

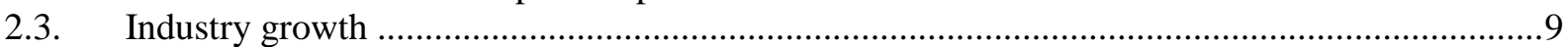

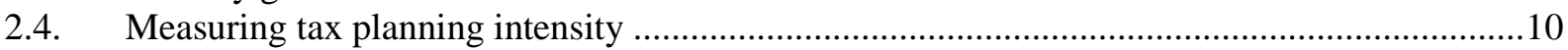

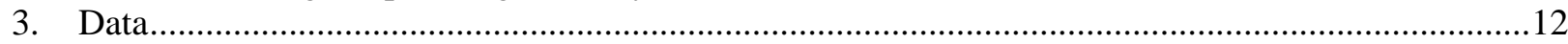

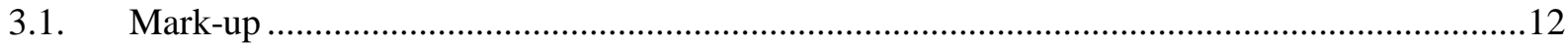

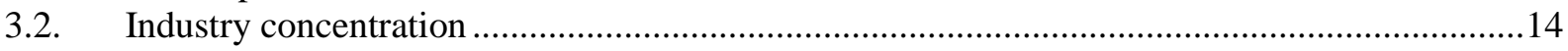

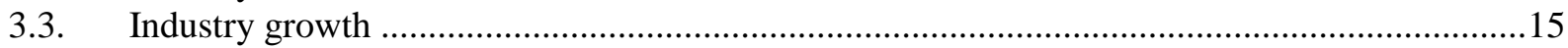

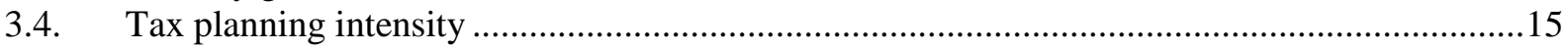

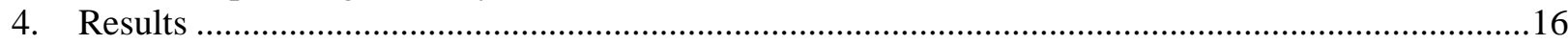

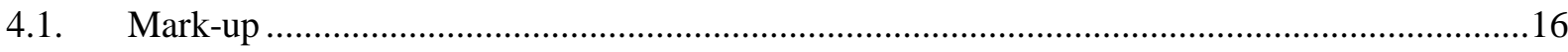

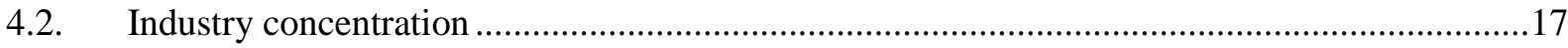

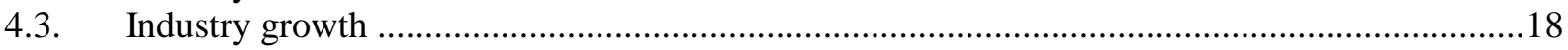

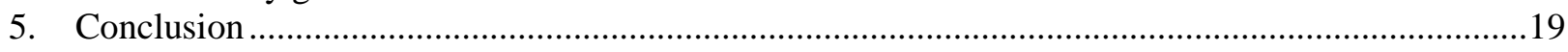

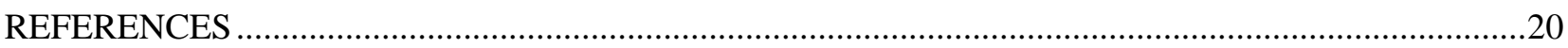

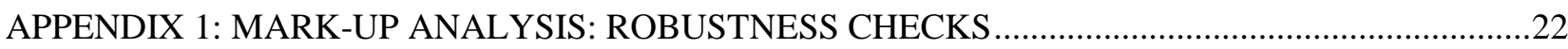

APPENDIX 2: DETAIL OF THE INDUSTRY CONCENTRATION INDEX …....................................25

\section{Tables}

Table 1. Mark-up analysis: data coverage ..................................................................................

Table 2. Mark-up analysis: regression results ...............................................................17

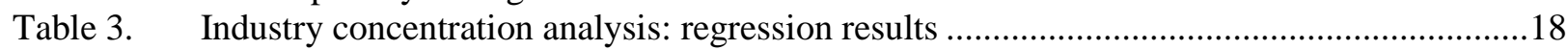

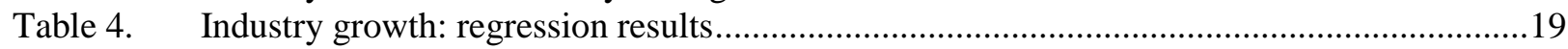

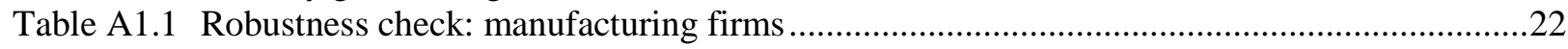

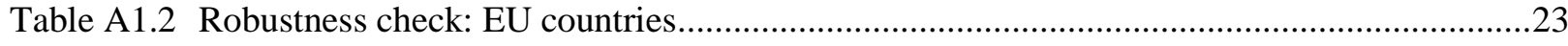

Table A1.3 Robustness check: Continuous firm size variable …......................................................24

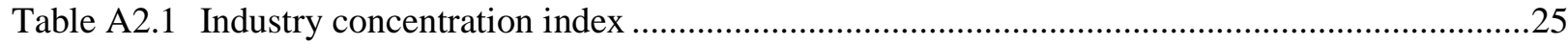

\section{Figures}

Figure 1. New index of market concentration............................................................................... 14 
ECO/WKP(2016)82

\title{
INTERNATIONAL TAX PLANNING, COMPETITION AND MARKET STRUCTURE
}

\author{
By Stéphane Sorbe and Åsa Johansson ${ }^{1}$
}

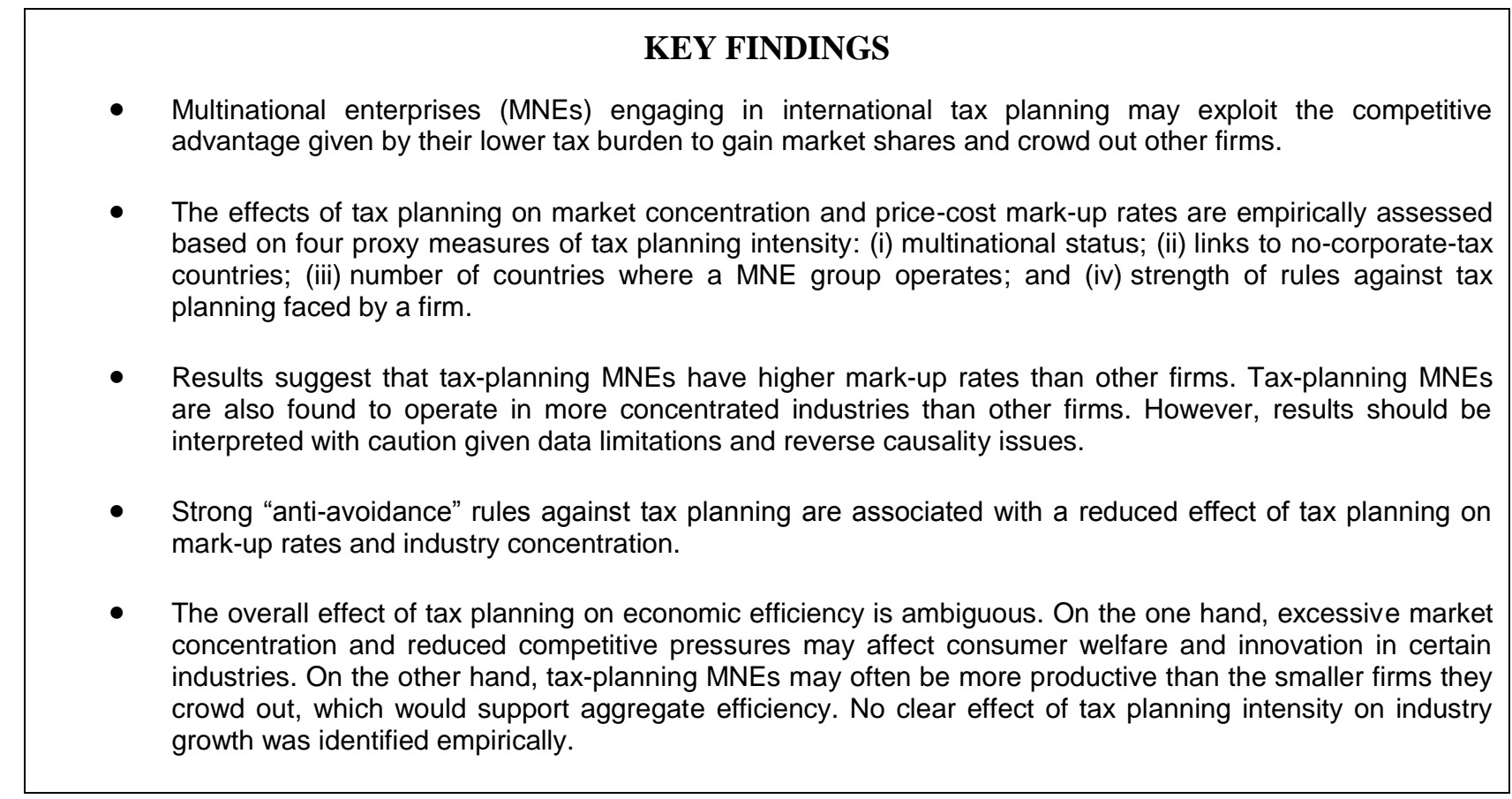

\section{Introduction and main findings}

1. Multinational enterprises (MNEs) take advantage of international differences between corporate tax systems to reduce their tax burden, for example by shifting profits to lower-tax rate countries. International tax planning (or so-called base erosion and profit shifting, i.e. BEPS) has been showed to reduce the average effective tax rate (ETR) of large MNE entities by $4-8 \frac{1}{2}$ percentage points relative to domestic (i.e. non-multinational) entities with similar characteristics (Johansson et al., 2016a). This difference can be even larger among very large and patenting firms. Tax-planning MNEs may exploit the competitive advantage given by their lower tax burden to gain market shares at the expense of other MNEs and domestic firms. They may do so either by reducing their prices or by investing more in product quality, service or branding depending on the nature of the market they service. In turn, tax-planning MNEs may increase their market power, potentially resulting in more concentrated market structures and affecting economic efficiency. Ultimately, it may allow these MNEs to obtain higher price-cost mark-up rates.

1. Åsa Johansson (asa.johansson@oecd.org) is with the OECD Economics Department and Stéphane Sorbe (stephane.sorbe@dgtresor.gouv.fr) was with the OECD Economics Department when this paper was produced. The authors would like to thank Christian Kastrop, Giuseppe Nicoletti, Jean-Luc Schneider from the Economics Department and Øystein B. Skeie (was with the OECD Economics Department when this paper was produced) for their valuable comments and suggestions and Sarah Michelson for excellent editorial support (also from the Economics Department). The paper has also benefitted from comments by OECD staff, members of Working Party No. 1 of the OECD Economic Policy Committee and members of Working Party No. 2 of the OECD Committee of Fiscal Affairs. 
2. The distortion in competition in favour of tax planning MNEs raises fairness and economic efficiency issues. Consumer welfare may suffer from insufficient competition and oligopolistic behaviours of firms if they translate into higher prices or reduced choice. Under certain conditions, high market concentration may also reduce innovation, for example by reducing MNEs' incentives to innovate to get ahead of competitors (Aghion et al., 2005; Gilbert, 2006). The allocation of capital is also affected as taxplanning MNEs may crowd out other MNEs and domestic firms. However, the overall effect on efficiency and welfare is unclear. On the one hand, large MNEs are on average more productive and innovative than the smaller firms they crowd out (Helpman et al., 2004; Bloom et al., 2012). On the other hand their incentives to innovate and increase their productivity may be reduced as compared to a situation without tax planning.

3. The potential competitive distortions induced by MNE tax planning are not documented in the empirical literature to our knowledge. This paper aims to fill this gap by exploring three avenues. It assesses: (i) if MNE groups engaged in international tax planning obtain higher mark-up rates than other firms; (ii) if industries with a strong presence of tax-planning MNEs are more concentrated than other industries; and (iii) if industries with a strong presence of tax-planning MNEs grow at a different pace than other industries.

4. The empirical analysis draws on firm-level data from the ORBIS database and industry-level data from the World Input-Output Database (WIOD). Mark-up rates of corporate groups are proxied by the ratio of pre-tax operating profit to turnover, in line with Aghion et al. (2005). Market concentration is measured at the aggregate industry level in 28 industries and 28 countries. In the absence of existing measure in the literature, this paper builds an industry concentration index based on data from the ORBIS database. The index is defined as the combined market share of the 10 largest firms in the industry (ranked by turnover) divided by the combined market share of the 100 largest.

5. The propensity of firms to engage in tax planning is not directly observed. The analysis relies on four proxy measures of tax planning intensity: (i) multinational status, exploiting the fact that nonmultinational firms cannot engage in international tax planning; (ii) links to tax havens, defined as nocorporate-tax countries; (iii) number of countries where a MNE group operates, as Johansson et al. (2016a) have shown that firms operating in many countries have a higher tax planning intensity than other firms; and (iv) strength of rules against tax planning faced by a firm; firms facing strong rules have been shown to engage less in tax planning (Overesch and Wamser, 2010; Buettner et al., 2012; Johansson et al. (2016a). All these proxy measures have their advantages and disadvantages and some of them entail reverse causality concerns, as discussed below. Nevertheless, the results obtained are broadly consistent across the four proxy measures, which support the robustness of the results.

6. The results suggest that MNEs engaged in tax planning obtain higher mark-up rates, after controlling for other factors affecting mark-up, such as size, productivity, industry, leverage, presence of patents or exposure to foreign competition. The mark-up rate of MNE groups is on average $9 \%$ higher than that of a non-multinational group with similar characteristics. MNE groups with links to no-corporate-tax countries benefit from an additional mark-up premium (+13\% relative to a MNE group without such links) and MNE groups operating in many countries as well ( $+4 \%$ for a group operating in 20 countries, as compared to the average MNE group, which operates in 5 countries). However, the direction of causality cannot be clearly established since a high mark-up can be a cause rather than a consequence of tax planning. Finally, MNE groups facing strong anti-avoidance rules against tax planning are found to have lower mark-up rates. This may stem from their lower tax planning opportunities, but might also reflect the cost of complying with anti-avoidance rules (e.g. compiling transfer price documentation).

7. Results on industry concentration are consistent with the mark-up findings. They show that industries with a high concentration of MNE groups, and especially of MNE groups likely to engage in international tax planning, are more concentrated than other industries. This is less the case when strong 
"anti-avoidance" rules against international tax planning are in place. This supports the hypothesis that MNEs engaged in international tax planning gain market shares at the expense of other firms. Similarly to the mark-up findings, the direction of causality is difficult to infer.

8. Results suggest no clear (positive or negative) impact of the presence of tax planning MNEs on industry growth, controlling for unobserved country and industry characteristics. This may reflect opposing forces. For example, higher concentration may discourage innovation in certain industries, while in others the reallocation of resources towards high-productivity MNEs may be growth-enhancing. More broadly, tax planning can affect industry growth through other channels that are not related to competition. For example, tax planning can reduce effective tax rates and the effect of cross-country corporate tax differences on the location of investment by tax planning MNEs, although this is achieved at the cost of additional distortions as compared with a situation in which corporate tax rates were cut across the board (Sorbe and Johansson 2016). Tax planning can also distort firm financing structures in favour of debt financing (Sorbe et al., 2016). Taking all these channels into account, the results suggest that the overall effect from tax planning on industry growth is ambiguous.

\section{Empirical strategy}

9. Tax planning gives certain MNEs a competitive advantage over other firms in the form of a lower tax burden (Johansson et al., 2016a). This may affect mark-up rates in different ways, depending on market structures and the nature of competition. Assuming that firms sell identical products and compete on price, the lower tax burden of a tax-planning MNE would allow it to reduce its price - and consequently its pretax mark-up - while maintaining the same after-tax profitability as compared to a situation without tax planning. This lower price would allow the tax planning MNE to gain market shares and it, increasing market concentration since tax planning MNEs tend to be larger than their competitors. Ultimately, after obtaining a dominant market position, the tax planning MNE may ultimately be able to increase its prices (and its mark-up) after obtaining a dominant market position.

10. Alternatively, if the MNE is pursuing a strategy of competing on attributes other than the price (e.g. quality, service and branding), it may use the cost-savings to further differentiate its products to achieve a larger market share and eventually a higher price and profit than its competitors (Porter, 1980). It may also use the tax savings to raise entry barriers to the market, for example by increasing advertising or R\&D spending (Sutton, 1991). Overall, the expected effect of tax planning is to increase the market share of tax planning MNEs at the expense of other firms. This is likely to increase market concentration, while the impact on mark-up will depend on the nature of the markets that are serviced by the tax-planning firms and therefore is a priori ambiguous.

\subsection{Mark-up: empirical specification}

11. Identifying empirically the effect of tax planning on mark-up rates poses several difficulties. The first is to identify tax-planning groups; this study relies on four different proxy measures discussed below (section 2.4). The second issue, which is related, is reverse causality. High-profitability MNE groups have more to gain from tax planning, so they may engage in tax planning more frequently than less profitable groups. Therefore, causality may run from high mark-up to tax planning rather than the opposite. The limitations induced by reverse causality are discussed in more detail for each of the four measures of tax planning. The third difficulty is that certain tax-planning strategies can artificially distort the mark-up rate of MNE entities. For example, profit shifting to lower-tax rate countries may artificially inflate mark-up rates in lower-tax rate countries and reduce them in higher-tax rate countries. To avoid any impact of this effect on the empirical analysis, this study focuses exclusively on the mark-up rate at the overall (consolidated) MNE group level, which does not directly depend on the location of profits.

12. The empirical strategy is to compare the mark-up rate of corporate groups having a different propensity to engage in international tax planning, while controlling for other group characteristics 
influencing mark-up (size, industry, productivity, innovative activity, foreign competition, etc.). In practice, the estimated equation is as follows:

$$
\text { Markup }_{g, c, i, t}=\alpha \text { TaxPlanning }_{g, c, i}+\beta X_{g, c, i, t}+\delta_{i}+\delta_{c}+\delta_{t}
$$

where Markup $_{g, c, i, t}$ is the mark-up rate of the MNE group $g$ (at the overall group level, i.e. based on consolidated group accounts), which operates in industry $i$, in year $t$ and has its headquarters in country $c$. The mark-up rate is proxied by the Lerner index, or price-cost margin, which is defined in practice as operating profit divided by turnover, in line with Aghion et al. (2005). ${ }^{2}$ The tax planning propensity (TaxPlanning $g_{g, c, i}$ ) is measured by one of four following options (discussed in section 2.4 below): (i) a dummy variable for multinational (as opposed to domestic) groups; (ii) a dummy variable for MNE groups with at least one link to a no-corporate-tax country; (iii) the number of countries where a MNE group operates; and (iv) the average strength of anti-avoidance rules against tax planning among the countries where the group operates.

13. The control vector $X_{g, c, i, t}$ is a set of group-specific variables affecting the mark-up rate, including size, leverage, productivity, patent ownership and exposure to foreign competition. Mark-up rates are expected to increase with firm size (measured by the number of employees in the group), reflecting the greater market power of large firms. ${ }^{3}$ Productivity (measured by firm-level total factor productivity) and patent ownership are also expected to have a positive effect, while the effect of leverage is a priori ambiguous. ${ }^{4}$ Exposure to foreign competition is measured by the average import penetration (measured at the industry level) across the countries (unweighted) where the group operates. A firm that is more exposed to foreign competition is expected to have a lower mark-up. $\delta_{i} \delta_{t}$ and $\delta_{c}$ are industry, year and country of headquarters fixed-effects capturing the different average mark-up rates in different industries, years and countries.

\subsection{Market concentration: empirical specification}

14. The approach is to test whether industries with a strong presence of tax planning MNE entities are more concentrated than other industries. There is no available measure of industry concentration in the existing economic data or literature. To remedy this issue, this study compiles a new industry concentration indicator derived from the firm-level ORBIS database. As data coverage varies overtime in this database, changes in the value of the indicator cannot be attributed with certainty to changes in industry concentration. Reflecting this issue, the empirical strategy is to use a cross-sectional regression for year 2009, where data coverage is highest in the available database and thus the concentration indicator is the most accurate. The following equation is estimated over a cross-section of industries and countries:

$$
\text { Concentration }_{i, c}=\alpha \text { TaxPlanningIntensity }{ }_{i, c}+\delta_{i}+\delta_{c}
$$

where Concentration ${ }_{i, c}$ is the market concentration of industry $i$ in country $c$. It is measured as the combined market share (based on turnover) of the 10 largest entities in industry $i$ and country $c$, divided by

2. Aghion et al. (2005) use sales instead of turnover. Turnover is used since it is closely related to sales and more widely available in the firm-level database used in this study. An alternative option to measure the price-cost margin is to use sales net of the expenditure on material and labour over total sales (Tybout, 2003; Altomonte and Ogliari, 2011).

3. Causality can also run in the opposite direction. Profitable groups are likely to have more opportunities to expand, resulting in larger size.

4. More profitable firms may self-finance more of their investments, leading to lower leverage. On the other hand, higher leverage may induce higher risks for investors, which may correspond to a higher expected profitability. 
the combined market share of the 100 largest entities in the same industry and country. Tax planning intensity (TaxPlanningIntensity ${ }_{i, c}$ ) is measured alternatively with four proxy variables consistent with those used in the mark-up analysis and further discussed in section 2.4 below: (i) the combined market share of MNE entities (as opposed to non-multinational entities) among the top-10 firms in industry $i$ and country $c$; (ii) the combined market share of MNE entities with a link to a no-corporate-tax country; (iii) the combined market share of top-10 MNE entities belonging to groups operating in at least five countries; and (iv) the combined market share of MNE entities among top-10 firms in the sector (i.e. the variable of option i) interacted with the strength of anti-avoidance rules in country $c . \delta_{i}$ and $\delta_{c}$ are dummies for industry and country, which capture common characteristics of certain industries and countries. For example, utilities or telecom industries tend to have a relatively high concentration because of large fixed costs. Likewise, countries with relatively small domestic markets or weak competition enforcement are likely to have more concentrated industries on average.

15. Market concentration can reflect, among other things, the intensity of competition in an industry. However, it is not a perfect proxy for competition intensity, especially in tradable sectors. This is because a firm in an industry that is highly concentrated at the domestic level can still face strong competitive pressures from foreign competitors. Another limitation is that market concentration can only be computed at a relatively broad industry level (28 industries per country) due to data limitations, while in practice competition takes place at a much more detailed product-by-product level.

\subsection{Industry growth}

16. Tax planning may influence industry growth in several ways. One channel is competition. Under certain circumstances, excessive concentration and a lack of competitive pressures may reduce innovation and incentives to get ahead of competitors (Aghion et al., 2005; Gilbert, 2006), which can ultimately reduce industry growth. On the other hand, large MNEs are on average more productive, innovative and exposed to competition than other firms (Helpman et al., 2004; Bloom et al., 2012). If tax planning MNEs are more productive than the firms they crowd out, a reallocation of resources towards them may enhance aggregate efficiency and support growth. ${ }^{5}$ This would suggest that the overall effect of tax planning on efficiency is a priori unclear.

17. Tax planning may also affect growth through channels that are not related to competition. In particular, tax planning reduces effective tax rates and the effect of cross-country corporate tax differences on the location of investment by tax planning MNEs, although this is achieved at the cost of additional distortions as compared with a situation in which corporate tax rates were cut across the board (Sorbe and Johansson 2016). Tax planning can also lead to higher leverage of MNEs, which can make them more vulnerable to income shocks and may hamper industry growth in adverse economic circumstances (Sorbe et al., 2016).

18. The empirical strategy to identify the effect of tax planning on industry growth is to compare the output growth rate of industries having different shares of MNEs likely to engage in tax planning. The following equation is estimated over a cross-section of industries and countries:

$$
\text { Growth }_{i, c}=\alpha \text { TaxPlanningIntensity } i_{i, c}+\delta_{i}+\delta_{c}
$$

where Growth $_{i, c}$ is the total output growth rate accumulated over 1999-2009 in industry $i$ in country $c$. Tax planning intensity (TaxPlanningIntensity ${ }_{i, c}$ ) is the same variable (with four different options) as in the market concentration analysis. $\delta_{i}$ and $\delta_{c}$ are dummies for industry and country, which capture common

5. Indeed, there is empirical evidence that in some countries, a large share of resources is used by unproductive (i.e. small and non-innovative) firms, which may crowd out activities by more productive MNEs (Andrews and Criscuolo, 2013). 
trends in certain industries and countries, such as the rapid growth of emerging economies and industries related to information and communications technology (ICT) over the period.

\subsection{Measuring tax planning intensity}

19. The intensity of tax planning of a firm or an industry is not directly observed. Indeed, the full picture of the location of activities, profits and tax payments of a MNE group in all countries where it operates is generally not available. This hinders the construction of a direct measure of profit shifting intensity based on the relative distribution of profit and activity across countries. A number of financial indicators are available at the group-level, such as the effective tax rate, but they cannot directly be used to measure tax planning intensity. This is because different groups operate in different sets of countries where they face different tax rates, meaning that the worldwide effective tax rates of different MNE groups are not easily comparable.

20. This study uses four proxy measures of tax planning intensity and uses them consistently in the three parts of the analysis (mark-up, market concentration and industry growth). These measures build on the results from Johansson et al. (2016a), which assesses tax planning based on the financial accounts of MNE groups (where they are available) and the list of countries where these groups operate (as identified based on the available firm ownership information). The results from Johansson et al. (2016a) indicate which types of firms engage more intensively in tax planning (e.g. firms operating in many countries, firms facing weaker anti-avoidance rules). The four measures are the following:

(i) Comparing MNEs and domestic firms. The rationale is that MNEs can engage in international tax planning, while domestic (i.e. non-multinational) firms cannot. For example, Johansson et al. (2016a) shows that tax planning reduces the ETR of large MNE entities by an average 5 percentage points relative to domestic firms, controlling for other firm characteristics. A limitation of this approach is that MNEs and domestic firms differ in many ways (e.g. size, productivity) that may influence their mark-up. The analysis includes a number of control variables (size, productivity, leverage, presence of patents and exposure to foreign competition) to eliminate the effect of these differences. Still, one cannot exclude that other (unobserved) differences between MNEs and domestic firms affect the results. ${ }^{6}$

The industry concentration analysis compares industries with different shares of MNEs and domestic firms. Data are aggregated at the industry level, so it is not possible to control for differences between MNEs and domestic firms. An important limitation is that firms in more concentrated industries tend to be larger (e.g. because of large fixed costs) and thus are more likely to be MNEs, since MNEs are on average larger than domestic firms. This implies that if MNEs are more represented in concentrated industries, it is not necessarily related to tax planning.

In the industry growth analysis, a similar issue of reverse causality may exist. Industries with a strong presence of MNEs are likely to benefit from technological spillovers from these MNEs, since MNEs tend to be more innovative than domestic firms. Therefore, they may grow faster than other industries.

(ii) Links to no-corporate-tax countries. Since no-corporate-tax countries are mostly small economies, a presence by a multinational group in one of these countries is often related to a tax planning scheme. A number of studies provide evidence of the role of tax havens in tax planning schemes (e.g. Grubert, 2003; Desai et al., 2006; Johansson et al., 2016 a). The main limitation with this measure of tax planning intensity is reverse causality. Firms that are ex ante more profitable have

6. Another limitation is that there exists few large domestic firm of a size comparable to the largest MNEs, making the comparison fragile among very large firms. 
more to gain from shifting profits to no-corporate-tax countries and thus have more incentives to set up affiliates in these countries in order to shift profits there.

(iii) MNEs present in many countries. MNEs present in many countries have a higher tax planning intensity, both in terms of profit shifting and exploiting mismatches between tax systems (Johansson et al., 2016a). This probably reflects that MNEs present in many countries have access to a wider range of potentially mismatching tax systems and bilateral tax treaties that increase "treaty abuse" opportunities. They also tend to be larger and thus have more resources to spend on tax optimisation strategies. Similarly to the links to no-corporate-tax countries, this measure entails reverse causality concerns. For example, if a high-profitability MNE sets up an affiliate in a nocorporate-tax country, this will increase, at least at the margin, the number of countries where it operates. In addition, ex ante more profitable groups have greater opportunities to develop their activities than other groups, which may in some cases involve expanding to more countries. However, this expansion may take time, meaning that the number of countries in the group reflects past more than current profitability. Furthermore, expansion may not always involve expanding to new countries. In some cases, firms may grow within the countries where they already operate. This suggests that the firm size variable (based on employment) is more likely to capture such expansion effect than the number of countries, which mitigates the reverse causality concern.

In the industry concentration analysis, one limitation (similar to the one in option i) is that MNEs operating in many countries tend to be larger than other MNEs. The large size of these MNEs implies that they are more likely than other firms to be part of concentrated markets.

(iv) Anti-avoidance strength. Strong anti-avoidance rules have been shown to reduce profit shifting (Overesch and Wamser, 2010; Buettner et al., 2012; Johansson et al., 2016a). In the mark-up analysis, the average anti-avoidance strength faced by a MNE group is measured by the unweighted average of the anti-avoidance strength classification among the countries where the group operates (see Johansson et al., 2016b) for details of the anti-avoidance classification). A limitation is that the unweighted average does not reflect the size of group activities in each country. ${ }^{7}$ Another caveat is that strong anti-avoidance rules have been found to reduce the overall profitability of MNE groups (Johansson et al., 2016a), presumably because of compliance costs for firms (e.g. costly transfer pricing documentation). A higher mark-up for groups facing relatively lax anti-avoidance rules could reflect low compliance costs as well as gains from tax planning.

In the industry concentration analysis, the approach is to interact the share of MNEs in an industry with the anti-avoidance strength in the country. The empirical setting is a difference-in-difference framework in the spirit of Rajan and Zingales (1998). The hypothesis is that strong anti-avoidance rules reduce industry concentration mainly in industries with a high share of MNEs, since only the tax-planning intensity of MNEs is impacted by anti-avoidance rules.

21. Reflecting the reverse causality concerns discussed above, the preferred tax planning measure in the mark-up analysis is the share of MNEs present in many countries. In the industry concentration and the industry growth analysis, the preferred measure is the strength of anti-avoidance interacted with the share of MNEs. Throughout the paper, results are presented for all four measures. Results are broadly consistent across the four measures of tax planning intensity.

7. Because of limited availability of the unconsolidated financial accounts of group members, using weights would sizeably reduce data coverage. 


\section{ECO/WKP(2016)82}

\section{Data}

22. Data on mark-up rates, industry concentration and measures of tax planning intensity are all derived from the ORBIS database. The ORBIS database contains financial account data, both at the consolidated (i.e. group-wide) and unconsolidated (i.e. entity specific) level, and ownership information of firms worldwide. The database is compiled by Bureau Van Dijk based on information from different sources (e.g. chambers of commerce, local public authorities or credit institutions). It was processed to ensure consistency across countries by the OECD Statistics Directorate (Pinto Ribeiro et al., 2010; Ragoussis and Gonnard, 2012). An additional processing was implemented for this project to identify corporate groups (Appendix 2 of Johansson et al., 2016a, Menon, 2016) and to further remove reporting errors and implausible values (Appendix 3 of Johansson et al., 2016a). The sample contains firms in 46 countries (mainly OECD and G20), as well as information on links to countries outside the sample.

\subsection{Mark-up}

23. Mark-up rates are proxied by the ratio of operating profit (EBIT) to turnover, at the consolidated level. Extreme values of the mark-up rate (above 50\% or negative), which may reflect reporting errors as well as exceptional events (e.g. court rulings) are dropped. ${ }^{8}$ For the same reason, extreme values of the explanatory variables (leverage, total factor productivity) are also dropped. To further improve data reliability, small corporate groups (less than 50 employees) are dropped from the analysis. Coverage appears well-balanced across countries, although the number of domestic groups is small in certain countries (Table 1). In contrast with analyses based on unconsolidated accounts from ORBIS (e.g. Johansson et al., 2016a), the United States are well represented in the sample. The sample covers the period 2000-10, with coverage slightly increasing over time.

8. Results are robust to a less drastic cleaning, which consists of keeping all observations with a mark-up rate between $-10 \%$ and $100 \%$. 
ECO/WKP(2016)82

Table 1. Mark-up analysis: data coverage

Number of observations of consolidated firm accounts by country (2000-10)

\begin{tabular}{|c|c|c|}
\hline Country & $\begin{array}{l}\text { MNE accounts } \\
\text { (by country of } \\
\text { headquarters) }\end{array}$ & $\begin{array}{l}\text { Domestic group } \\
\text { accounts }\end{array}$ \\
\hline Australia & 134 & 35 \\
\hline Austria & 51 & 1 \\
\hline Belgium & 1130 & 684 \\
\hline Canada & 25 & 4 \\
\hline China & 161 & 1015 \\
\hline Denmark & 32 & 2 \\
\hline Finland & 1516 & 2255 \\
\hline France & 294 & 143 \\
\hline Germany & 1733 & 1283 \\
\hline Greece & 115 & 31 \\
\hline Ireland & 52 & 3 \\
\hline Israel & 144 & 5 \\
\hline Italy & 1928 & 3115 \\
\hline Japan & 2401 & 5251 \\
\hline Malaysia & 33 & 0 \\
\hline Mexico & 33 & 28 \\
\hline Netherlands & 212 & 4 \\
\hline Norway & 31 & 23 \\
\hline Poland & 33 & 81 \\
\hline Portugal & 136 & 199 \\
\hline Singapore & 50 & 0 \\
\hline South Africa & 35 & 5 \\
\hline Spain & 1631 & 1542 \\
\hline Sweden & 3565 & 5486 \\
\hline Switzerland & 273 & 71 \\
\hline United Kingdom & 1728 & 8384 \\
\hline United States & 4090 & 2034 \\
\hline Total & 21566 & 31684 \\
\hline
\end{tabular}

Note: countries with less than 25 observations of MNE accounts are excluded from the sample.

Source: OECD calculations based on the ORBIS database.

24. Total factor productivity (TFP) is computed assuming a Cobb-Douglas production function, with fixed weights of one third for capital (measured as fixed assets) and two thirds for labour (measured as wage costs). Coverage of value added and wage costs is limited in certain countries (e.g. in the United States) and these variables are imputed when they are not initially available in ORBIS, similarly to Gal (2013). Wages costs are imputed as the product of firm-level employment and the average wage in the industry computed from ORBIS. Value added is imputed as the sum of EBITDA and wage costs. Results are robust to excluding the imputed observations.

25. Leverage is measured as the debt-to-equity ratio of the corporate group. The presence of patents is identified based on a merger of ORBIS database with the PATSTAT patent database (see Skeie et al., 
(2016) for details). Patenting groups are defined as corporate groups having a depreciated patent stock of at least 10 patents in at least one year of the sample. ${ }^{9}$

\subsection{Industry concentration}

26. The analysis on industry concentration draws on a new index of industry concentration constructed using unconsolidated firm accounts from the ORBIS database. The index is defined as the combined market share (based on turnover) of the 10 largest firms in the industry and a country, divided by the market share of the 100 largest. The index is computed for 28 industries in 28 countries. Industrycountry couples with less than 100 firms in ORBIS are eliminated from the sample. One limitation is the quality of coverage of the ORBIS database. Coverage is broadly even across industries and above 50\% (among large firms) across many European countries. However, certain countries (especially the United States) are under-represented (see Figure 3 in Johansson et al., 2016a). Coverage of ORBIS varies over time, implying that the concentration index cannot be compared between different years since changes in the index could reflect changes in data coverage. Therefore, the index is only computed for the year 2009, where coverage of the available ORBIS dataset is the most extensive.

27. As expected, the concentration index is high in industries with large fixed costs (e.g. posts and telecommunications, utilities, car producing, mining). It also tends to be high in smaller countries, where the domestic market is not sufficiently large to have many large firms (Figure 1). Detailed values of the concentration index for all countries and industries are provided in Appendix 2.

Figure 1. New index of industry concentration

Index between 0 (least concentrated) and 1 (most concentrated)

Panel A: Average concentration by industry, 2009

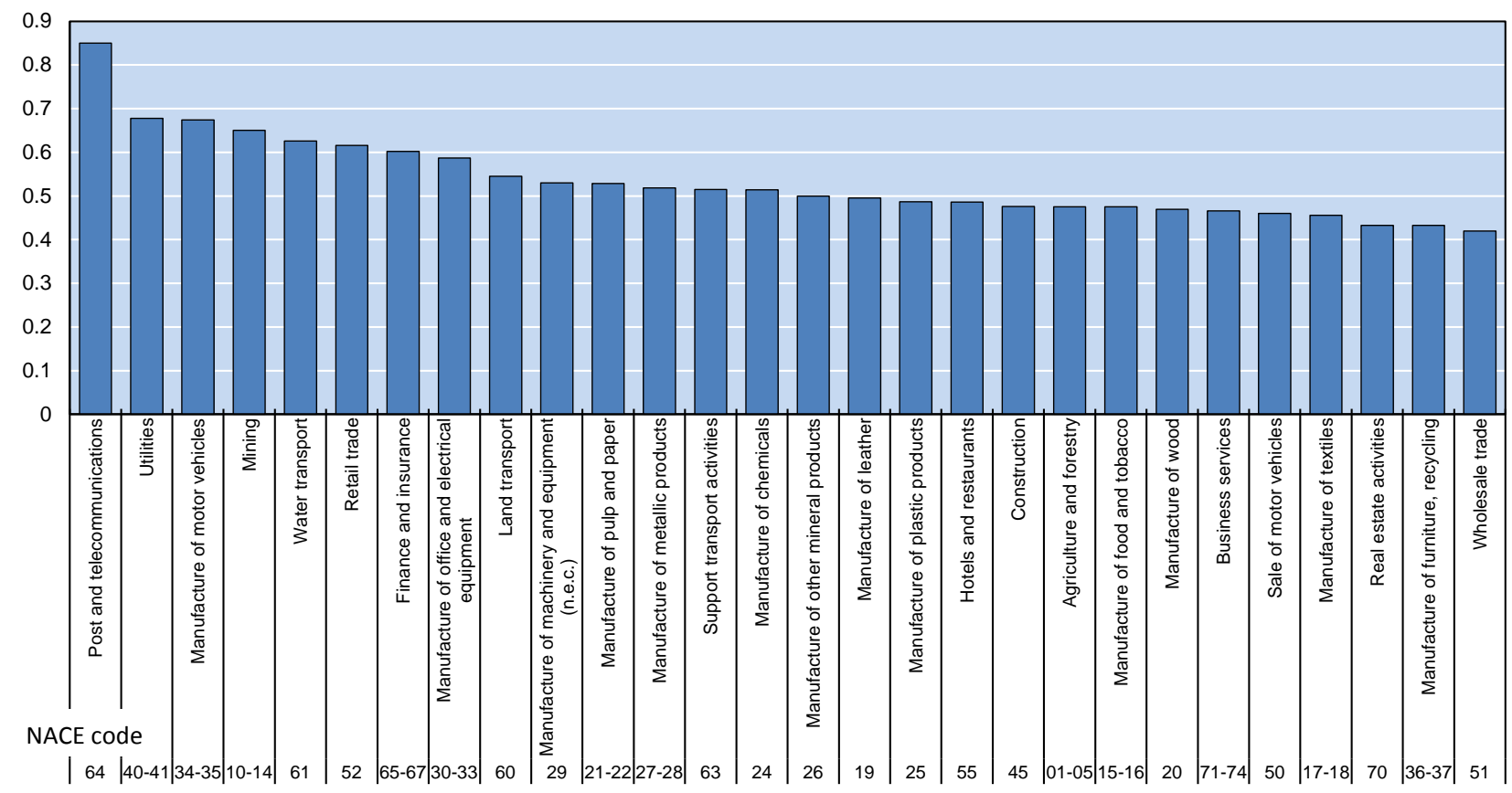

9. The depreciated patent stock is estimated based on a perpetual inventory method, assuming a constant depreciation rate of $15 \%$ per year for all patents (see Andrews et al. 2014 for details). 
Panel B: Average concentration by country, 2009

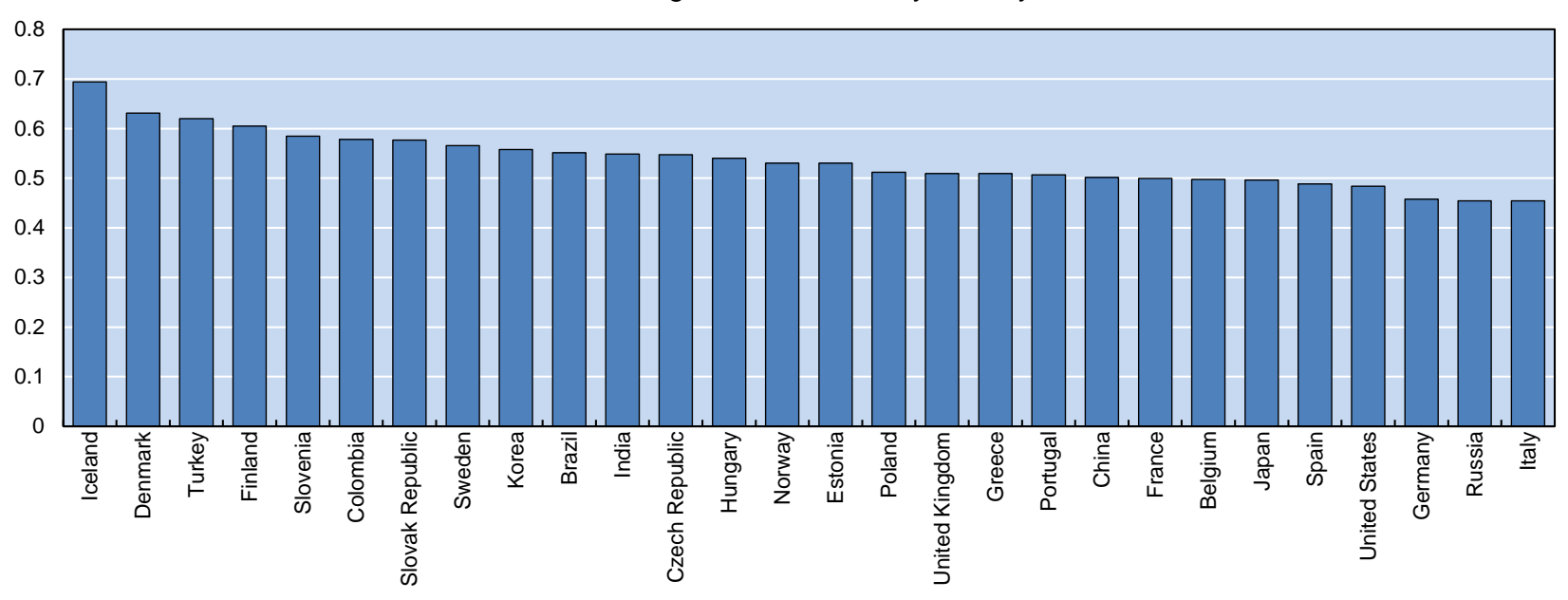

Source: OECD calculations based on ORBIS. The index is the combined market share of share of top-10 firms (by turnover) in an industry and a country divided by market share of top-100 firms in the same industry and country.

\subsection{Industry growth}

28. Data on industry growth is sourced from the July 2014 vintage of the World Input-Output Database (WIOD). This database contains industry level accounts for 30 industries and 40 countries (mainly OECD and G20) over 1995-2011. Industry growth is measured as the cumulated growth rate of value added (at constant prices) over 1999-2009. The cumulated growth rate over 2004-2009 is used as an alternative, which yields similar results.

\subsection{Tax planning intensity}

29. MNEs and domestic groups are identified with a sophisticated algorithm iterating on the ownership information in the ORBIS database (see Johansson et al., 2016a), Appendix 2; Menon, 2016 forthcoming). The resulting information on group structures is used to identify links to no-corporate-tax countries and count the number of countries where groups operate. One limitation is that some links may not be reported in the ORBIS database. It is difficult to assess the magnitude and importance of the missing links due to general lack of data on actual links. Nevertheless, an important number of links to nocorporate tax countries is identified (see Figure 2 of Johansson et al., 2016a). For example, among the top500 US firms (Fortune 500 list for 2013), Citizens for Tax Justice (CTJ, 2014) identify 362 firms having links to "tax havens". Of these 362 firms, 266 (i.e. 72\%) have been identified in ORBIS. Among these 266 identified firms, at least one tax haven link is identified in ORBIS in 184 cases, i.e. in more than two-thirds of cases.

30. The strength of anti-avoidance rules against international tax planning and withholding taxes is taken from Johansson et al. (2016b). Rules strength is measured on a 0-8 scale taking into account five key dimensions of the rules: (i) the comprehensiveness of documentation and disclosure requirements on transfer prices; (ii) the existence and strictness of rules limiting interest deductibility (thin capitalisation and interest-to-earnings rules); (iii) the existence of a general anti-avoidance rule (GAAR); (iv) the existence of a controlled foreign-company (CFC) rule.; and (v) withholding taxes on interest, dividends and royalties, taking into account tax treaties. As rules are complex and country-specific, the classification inevitably relies on simplifying assumptions (see Johansson et al., (2016b) for details). For example, enforcement practices (e.g. frequency of tax audits, penalties in case of non-compliance) are not captured. Another limitation is that the analysis relies on the anti-avoidance strength in $2005,{ }^{10}$ which is towards the

10. The classification was only compiled for the years 2005 and 2014 . 
middle of the sample period, and does not take into account that the strength of rules may have changed over the period.

31. As the design of GAARs and CFC rules is very country-specific, the classification only reflects the existence or non-existence of a rule, which is simplistic. As an alternative, results are also presented using a $0-6$ classification excluding GAARs and CFC rules.

\section{Results}

\subsection{Mark-up}

32. Results support the hypothesis that international tax planning is associated with higher mark-up rates (Table 2). The mark-up rate of MNEs is about 0.9 percentage point (or 9\%) higher than domestic firms, after controlling for other firm characteristics (column 1). MNEs with links to no-corporate-tax countries are found to have a mark-up rate 1.3 percentage point (about 13\%) higher than other MNEs (column 2). This large difference may partly reflect reverse causality as discussed above (highly-profitable firms have more incentives to set up affiliates in no-tax countries). The mark-up rate of MNEs increases with the number of countries where they operate. A MNE operating in 20 countries would have a 0.4 percentage point (4\%) higher mark-up rate than the average MNE, which operates in 5 countries (column 3). Finally, MNE groups facing stronger anti-avoidance rules have a lower mark-up rate. This holds for both the 0-6 and the 0-8 anti-avoidance classification. An increase in average anti-avoidance strength from a moderately strong stance (score of 3-4 on the 0-8 scale) to a relatively strong one (score of $5-6$ ) is associated with a reduction in mark-up rates by 0.7 percentage point (7\%) (column $4 \mathrm{~b}$ ). However, this may partly reflect higher compliance costs associated with stronger rules. Other explanatory variables are in line with expectations. Mark-up tends to increase with firm size, productivity and the presence of patents and to decrease with leverage. 
Table 2. Mark-up analysis: regression results

\begin{tabular}{|c|c|c|c|c|c|}
\hline & $\begin{array}{c}\text { (1) } \\
\text { MNE vs. } \\
\text { domestic }\end{array}$ & $\begin{array}{l}\text { (2) } \\
\text { Link to no-tax } \\
\text { country }\end{array}$ & $\begin{array}{c}(3) \\
\text { MNE } \\
\text { operating in } \\
\text { many } \\
\text { countries }\end{array}$ & $\begin{array}{c}(4 a) \\
\text { Anti- } \\
\text { avoidance } \\
\text { strength } \\
\text { (0-6 classif.) }\end{array}$ & $\begin{array}{c}(4 b) \\
\text { Anti- } \\
\text { avoidance } \\
\text { strength } \\
\text { (0-8 classif.) }\end{array}$ \\
\hline Dependent variable & \multicolumn{5}{|c|}{ Markup rate (EBITDA/Turnover) at the corporate group level } \\
\hline Year dummies & yes & yes & yes & yes & yes \\
\hline Country of headquarters dummies & yes & yes & yes & yes & yes \\
\hline Industry dummies & yes & yes & yes & yes & yes \\
\hline MNE group & $\begin{array}{c}0.944^{* * *} \\
{[0.076]}\end{array}$ & & & & \\
\hline Link to no-tax country & & $\begin{array}{c}1.343^{\star * *} \\
{[0.380]}\end{array}$ & & & \\
\hline Number of countries of operation & & & $\begin{array}{c}0.024^{\star * *} \\
{[0.008]}\end{array}$ & & \\
\hline Strong anti-avoidance & & & & $\begin{array}{c}-0.270^{\star \star \star *} \\
{[0.098]}\end{array}$ & $\begin{array}{c}-0.351^{* * *} \\
{[0.086]}\end{array}$ \\
\hline Small (<249 employees) - base level & 0 & 0 & 0 & 0 & 0 \\
\hline Large (250-999 employees) & $\begin{array}{c}0.417^{* * *} \\
{[0.079]}\end{array}$ & $\begin{array}{c}0.830^{* * *} \\
{[0.132]}\end{array}$ & $\begin{array}{c}0.808^{* * *} \\
{[0.132]}\end{array}$ & $\begin{array}{c}0.858^{* * *} \\
{[0.133]}\end{array}$ & $\begin{array}{c}0.849^{* * *} \\
{[0.132]}\end{array}$ \\
\hline Very large (1.000-9.999 employees) & $\begin{array}{c}0.860^{\star * *} \\
{[0.108]}\end{array}$ & $\begin{array}{c}1.109^{\star * *} \\
{[0.155]}\end{array}$ & $\begin{array}{c}1.041^{* * *} \\
{[0.159]}\end{array}$ & $\begin{array}{c}1.151^{\star \star *} \\
{[0.156]}\end{array}$ & $\begin{array}{c}1.142^{* \star *} \\
{[0.156]}\end{array}$ \\
\hline Huge (10.000+ employees) & $\begin{array}{c}1.208^{\star * *} \\
{[0.187]}\end{array}$ & $\begin{array}{c}1.134^{\star \star *} \\
{[0.229]}\end{array}$ & $\begin{array}{c}0.999^{\star * *} \\
{[0.253]}\end{array}$ & $\begin{array}{c}1.286^{* * *} \\
{[0.227]}\end{array}$ & $\begin{array}{c}1.273^{\star \star \star} \\
{[0.227]}\end{array}$ \\
\hline Productivity (TFP) & $\begin{array}{c}2.216^{\star * *} \\
{[0.067]}\end{array}$ & $\begin{array}{c}2.931^{* \star *} \\
{[0.109]}\end{array}$ & $\begin{array}{c}2.936^{* * *} \\
{[0.109]}\end{array}$ & $\begin{array}{c}2.930^{* * *} \\
{[0.109]}\end{array}$ & $\begin{array}{c}2.927^{\star \star \star} \\
{[0.109]}\end{array}$ \\
\hline Debt-to-equity ratio & $\begin{array}{l}0.004 \\
{[0.020]}\end{array}$ & $\begin{array}{c}-0.111^{* * *} \\
{[0.032]}\end{array}$ & $\begin{array}{c}-0.108^{* * *} \\
{[0.032]}\end{array}$ & $\begin{array}{c}-0.110^{* * *} \\
{[0.032]}\end{array}$ & $\begin{array}{c}-0.108^{* * *} \\
{[0.032]}\end{array}$ \\
\hline Patenting group & $\begin{array}{c}1.662^{* * *} \\
{[0.135]}\end{array}$ & $\begin{array}{c}1.572^{\star \star *} \\
{[0.156]}\end{array}$ & $\begin{array}{c}1.538^{* * *} \\
{[0.156]}\end{array}$ & $\begin{array}{c}1.595^{\star * *} \\
{[0.155]}\end{array}$ & $\begin{array}{c}1.594^{* * *} \\
{[0.155]}\end{array}$ \\
\hline Exposure to foreign competition & $\begin{array}{l}0.005 \\
{[0.005]}\end{array}$ & $\begin{array}{c}-0.004 \\
{[0.006]}\end{array}$ & $\begin{array}{l}-0.005 \\
{[0.006]}\end{array}$ & $\begin{array}{c}-0.014^{*} \\
{[0.007]}\end{array}$ & $\begin{array}{c}-0.017^{* *} \\
{[0.007]}\end{array}$ \\
\hline Observations & 53,250 & 21,566 & 21,566 & 21,566 & 21,566 \\
\hline R-squared & 0.201 & 0.212 & 0.211 & 0.211 & 0.212 \\
\hline AdjR2 & 0.200 & 0.209 & 0.208 & 0.208 & 0.208 \\
\hline
\end{tabular}

All regressions are ordinary least squares (OLS). ${ }^{* * *}$ indicates significance at the $1 \%$ level, ${ }^{* *}$ at the $5 \%$ level and ${ }^{*}$ at the $10 \%$ level. Robust standard errors are presented under brackets. The sample in column 1 consists of both multinational and non-multinational corporate groups (consolidated financial accounts) over 2000-10. The sample in columns 2 to 4 consists only of multinational groups. Groups with less than 50 employees are excluded.

33. These results are largely robust to several variants: (i) restricting the sample to EU countries; (ii) restricting the sample to manufacturing industries; (iii) replacing the discrete size variable by a continuous variable (logarithm of employment). Nevertheless, in a few of these robustness checks, the tax planning intensity variable is no longer statistically significant (Appendix 1).

\subsection{Industry concentration}

34. The results support the hypothesis that international tax planning is associated with higher industry concentration (Table 3). Industries with a strong presence of MNEs tend to be more concentrated. 


\section{ECO/WKP(2016)82}

However, this may reflect that MNEs tend to be larger than other firms, which makes them more likely to belong to concentrated industries (column 1). For a given share of MNEs in an industry, a strong presence of MNEs with links to no-corporate-tax countries also increases concentration, although the effect is not statistically significant (column 2). A strong presence of MNEs operating in many countries significantly increases concentration, although this may also to some extent reflect a size effect (column 3).

35. Finally, results show that in industries with a strong presence of MNEs, strong anti-avoidance rules against international tax planning are associated with lower market concentration. However, this effect is statistically significant only with the 0-6 anti-avoidance classification excluding CFC rules and GAARs (column 4a). For example, in an industry with a market share of MNEs of 85\% among top-10 firms (the $75^{\text {th }}$ percentile of the distribution), increasing anti-avoidance strength from a level of 2 to 4 on the 0-6 scale is associated with a reduction in the combined market share of the ten largest firms in the industry by about 6 percentage points.

Table 3. Industry concentration analysis: regression results

\begin{tabular}{|c|c|c|c|c|c|}
\hline & $\begin{array}{c}(1) \\
\text { MNEs }\end{array}$ & $\begin{array}{l}\text { (2) } \\
\text { Link to no-tax } \\
\text { country }\end{array}$ & $\begin{array}{c}(3) \\
\text { MNE } \\
\text { operating in } \\
\text { many } \\
\text { countries }\end{array}$ & $\begin{array}{c}\text { (4a) } \\
\text { Anti- } \\
\text { avoidance } \\
\text { strength } \\
\text { (0-6 classif.) }\end{array}$ & $\begin{array}{c}(4 b) \\
\text { Anti- } \\
\text { avoidance } \\
\text { strength } \\
\text { (0-8 classif.) }\end{array}$ \\
\hline Dependent variable & \multicolumn{5}{|c|}{ Industry concentration } \\
\hline Country dummies & yes & yes & yes & yes & yes \\
\hline Industry dummies & yes & yes & yes & yes & yes \\
\hline Share of MNEs among top-10 firms & $\begin{array}{c}0.1515^{\star * *} \\
{[0.0237]}\end{array}$ & $\begin{array}{c}0.1433^{\star * *} \\
{[0.0244]}\end{array}$ & $\begin{array}{c}0.0638^{*} \\
{[0.0337]}\end{array}$ & $\begin{array}{c}0.2474^{\star * *} \\
{[0.0494]}\end{array}$ & $\begin{array}{c}0.2205^{\star * *} \\
{[0.0555]}\end{array}$ \\
\hline $\begin{array}{l}\text { Share of MNEs with link to no-tax } \\
\text { country among top-10 firms }\end{array}$ & & $\begin{array}{l}0.0409 \\
{[0.0332]}\end{array}$ & & & \\
\hline $\begin{array}{l}\text { Share of MNEs operating in at least } 5 \\
\text { countries among top- } 10 \text { firms }\end{array}$ & & & $\begin{array}{c}0.1184^{\star * *} \\
{[0.0314]}\end{array}$ & & \\
\hline $\begin{array}{l}\text { Share of MNEs among top- } 10 \text { firms } \\
\times \text { Strength of anti-avoidance rules }\end{array}$ & & & & $\begin{array}{c}-0.0314^{* *} \\
{[0.0149]}\end{array}$ & $\begin{array}{c}-0.0165 \\
{[0.0122]}\end{array}$ \\
\hline Observations & 661 & 661 & 661 & 661 & 661 \\
\hline R-squared & 0.506 & 0.508 & 0.519 & 0.511 & 0.508 \\
\hline AdjR2 & 0.462 & 0.462 & 0.475 & 0.466 & 0.463 \\
\hline
\end{tabular}

All regressions are ordinary least squares (OLS). ${ }^{* \star *}$ indicates significance at the $1 \%$ level, ${ }^{* *}$ at the $5 \%$ level and * at the $10 \%$ level. Robust standard errors are presented under brackets. The sample is a cross-section of 28 industries in 28 countries in 2009. Industry concentration is defined as the combined market share of the top-10 firms in an industry and a country (ranked by turnover) over the top-100 firms, computed from ORBIS unconsolidated firm-level data (see Appendix 2 for details).

\subsection{Industry growth}

36. The results suggest no clear link between the intensity of tax planning in an industry and output growth in this industry (Table 4). All four measures of tax planning intensity yield non-significant results. These results remain unchanged to replacing the ten-year cumulated industry growth by five-year growth (2004-09) as the dependent variable. Results are also unaffected by controlling for the share of patenting firms in the top-10 firms of an industry. 
Table 4. Industry growth: regression results

\begin{tabular}{|c|c|c|c|c|c|}
\hline \multirow[b]{3}{*}{ Dependent variable } & (1) & (2) & (3) & $(4 a)$ & $(4 b)$ \\
\hline & MNEs & $\begin{array}{l}\text { Link to no- } \\
\text { tax country }\end{array}$ & $\begin{array}{c}\text { MNE } \\
\text { operating in } \\
\text { many } \\
\text { countries }\end{array}$ & $\begin{array}{l}\text { Anti- } \\
\text { avoidance } \\
\text { strength } \\
\text { (0-6 classif.) }\end{array}$ & $\begin{array}{c}\text { Anti- } \\
\text { avoidance } \\
\text { strength } \\
\text { (0-8 classif.) }\end{array}$ \\
\hline & \multicolumn{5}{|c|}{ Industry growth } \\
\hline Country dummies & yes & yes & yes & yes & yes \\
\hline Industry dummies & yes & yes & yes & yes & yes \\
\hline Share of MNEs among top-10 firms & $\begin{array}{l}0.0028 \\
{[0.0064]}\end{array}$ & $\begin{array}{l}0.0057 \\
{[0.0067]}\end{array}$ & $\begin{array}{l}-0.0029 \\
{[0.0086]}\end{array}$ & $\begin{array}{l}0.0143 \\
{[0.0140]}\end{array}$ & $\begin{array}{l}0.0111 \\
{[0.0160]}\end{array}$ \\
\hline $\begin{array}{l}\text { Share of MNEs with link to no-tax country } \\
\text { among top-10 firms }\end{array}$ & & $\begin{array}{l}-0.0142 \\
{[0.0104]}\end{array}$ & & & \\
\hline $\begin{array}{l}\text { Share of MNEs operating in at least } 5 \\
\text { countries among top- } 10 \text { firms }\end{array}$ & & & $\begin{array}{l}0.0075 \\
{[0.0083]}\end{array}$ & & \\
\hline $\begin{array}{l}\text { Share of MNEs among top- } 10 \text { firms } \\
\times \text { Strength of anti-avoidance rules }\end{array}$ & & & & $\begin{array}{l}-0.0036 \\
{[0.0036]}\end{array}$ & $\begin{array}{l}-0.0019 \\
{[0.0031]}\end{array}$ \\
\hline Observations & 632 & 632 & 632 & 632 & 632 \\
\hline R-squared & 0.541 & 0.543 & 0.541 & 0.541 & 0.541 \\
\hline AdjR2 & 0.491 & 0.493 & 0.491 & 0.491 & 0.491 \\
\hline
\end{tabular}

All regressions are ordinary least squares (OLS). ${ }^{* *}$ indicates significance at the $1 \%$ level, ${ }^{* *}$ at the $5 \%$ level and ${ }^{*}$ at the $10 \%$ level. Robust standard errors are presented under brackets. The sample is a cross-section of 28 industries in 28 countries. Industry growth is defined as the cumulated output growth rate of the industry over the ten years to 2010.

37. The non-significant results suggest that there is no clear link between tax planning and industry value-added growth. This may reflect opposing forces at play across industries and countries. For example, tax planning may reduce incentives to get ahead of competitors and deter innovation in certain industries, while in some others the reallocation of resources towards high-productivity MNEs may have a positive effect on growth.

\section{Conclusion}

38. This paper provides novel empirical findings suggesting that MNEs engaged in tax planning can exploit their lower tax burden to increase their market share, resulting in more concentrated market and higher mark-up rates for these firms. Tax planning intensity is not directly observed, but the broad range of proxy indicators employed in the analysis gives consistent results both in terms of mark-up rates and industry concentration. In addition, anti-avoidance rules against international tax planning are found to be associated with lower mark-up rates and less concentrated markets. Nevertheless, results should be interpreted with caution given reverse causality issues and data limitations.

39. These findings have economic efficiency and welfare implications. More concentrated markets can result in insufficient competition, which can be detrimental to consumer welfare and innovation, at least under certain circumstances. By distorting the playing field between tax planning MNEs, other MNEs and domestic firms, tax planning can also alter the allocation of capital between firms. Still, if tax planning MNEs are more productive than the firms they crowd out, the overall effect on efficiency is unclear. Overall, reflecting these opposing forces, the analysis finds no clear (positive or negative) effect of tax planning intensity on industry growth. 


\section{REFERENCES}

Aghion, P., N. Bloom, R. Blundell, R. Griffith and P. Howitt (2005), "Competition and Innovation: An Inverted-U Relationship”, Quarterly Journal of Economics, MIT Press, Vol. 120, pp. 701-728.

Altomonte, C. and L. Ogliari (2011), "International trade and the competition dynamics of multiproduct firms", MICRO-DYN Working Paper, No. 07/11.

Andrews, D., C. Criscuolo and C. Menon (2014), "Do Resources Flow to Patenting Firms?: Cross-Country Evidence from Firm Level Data", OECD Economics Department Working Papers, No. 1127, OECD Publishing. http://dx.doi.org/10.1787/5jz2lpmk0gs6-en

Andrews, D. and C. Criscuolo (2013), "Knowledge-Based Capital, Innovation and Resource Allocation", OECD Economics Department Working Papers, No. 1046, OECD Publishing.

Bloom, N., R. Sadun and J. Van Reenen (2012), "Americans Do IT Better: US Multinationals and the Productivity Miracle”, American Economic Review, 102.

Buettner, T., M. Overesch, U. Schreiber and G. Wamser (2012), "The impact of thin capitalisation rules on the capital structure of multinational firms", Journal of Public Economics, Vol. 96, Issues 11-12.

CTJ (2014), Offshore Shell Games 2014: The Use of Offshore Tax Havens by Fortune 500 Companies, Citizens for Tax Justice.

Desai M., F. Foley and J. Hines (2006), "The demand for tax haven operations", Journal of Public Economics, Vol. 90.

Gal, P. (2013), "Measuring Total Factor Productivity at the Firm Level using OECD-ORBIS", OECD Economics Department Working Papers, No. 1049, OECD Publishing. http://dx.doi.org/10.1787/5k46dsb25ls6-en

Gilbert, R. (2006), "Looking for Mr. Schumpeter: Where Are We in the Competition-Innovation Debate?", Innovation Policy and the Economy, Vol. 6 (eds. A. Jaffe, J. Lerner and S. Stern), National Bureau of Economic Research.

Grubert, H. (2003), "Intangible Income, Intercompany Transactions, Income Shifting, and the Choice of Location", National Tax Journal, Vol. 56, No. 1.

Helpman, E., M. Melitz, and S. Yeaple (2004), "Export versus FDI with Heterogeneous Firms", American Economic Review, 94.

Johansson A., Skeie Ø., S. Sorbe and C. Menon (2016a), "Tax planning by multinational firms: firm-level evidence from a cross-country database", OECD Economics Department Working Papers No. 1355, OECD Publishing.

Johansson $\AA$., Skeie $\emptyset$. and S. Sorbe (2016b), “Anti-avoidance rules against international tax planning: a classification”, OECD Economics Department Working Papers No. 1356, OECD Publishing.

Menon, C. (2016), “An algorithm to identify multinational groups in ORBIS”, forthcoming. 
Overesch, M. and G. Wamser (2010), "Corporate tax planning and thin-capitalization rules: evidence from a quasi-experiment", Applied Economics, Vol. 42.

Pinto Ribeiro, S., S. Menghinello and K. Backer (2010), "The OECD ORBIS Database: Responding to the Need for Firm-Level Micro-Data in the OECD", OECD Statistics Working Papers, No. 2010/01, OECD Publishing. http://dx.doi.org/10.1787/5kmhds8mzj8w-en

Porter, M. (1980) “Competitive Strategy”, Free Press, New York, 1980.

Ragoussis, A. and E. Gonnard (2012), “The OECD-ORBIS Database - Treatment and Benchmarking Procedures", OECD mimeo.

Rajan, R. and L. Zingales (1998), "Financial dependence and growth", American Economic Review, Vol. 88.

Skeie Ø., Johansson, Å., Menon C., and S. Sorbe (2016), "Innovation, patent location and tax planning by multinationals", OECD Economics Department Working Papers No. 1360, OECD Publishing.

Sorbe S. and Å. Johansson (2016b), "International tax planning and fixed investment”, OECD Economics Department Working Papers No. 1361, OECD Publishing.

Sorbe S., Johansson $\AA$., and $\varnothing$., Skeie (2016), "Debt and tax planning by multinationals", OECD Economics Department Working Papers No. 1357, OECD Publishing.

Sutton, J. (1991), "Sunk costs and market structure: Price competition, advertising, and the evolution of concentration", MIT Press, Cambridge, Mass.

Tybout, J. (2003), "Plant- and Firm-level Evidence on the 'New' Trade Theories", in Handbook of International Trade (eds. E. Kwan Choi and James Harrigan), Oxford: Basil-Blackwell. 


\section{APPENDIX 1: MARK-UP ANALYSIS: ROBUSTNESS CHECKS}

Table A1.1 Robustness check: manufacturing firms

\begin{tabular}{|c|c|c|c|c|c|}
\hline & $\begin{array}{c}\text { (1) } \\
\text { MNE vs. } \\
\text { domestic }\end{array}$ & $\begin{array}{l}\text { (2) } \\
\text { Link to no-tax } \\
\text { country }\end{array}$ & $\begin{array}{c}\text { (3) } \\
\text { MNE } \\
\text { operating in } \\
\text { many } \\
\text { countries }\end{array}$ & $\begin{array}{c}\text { (4a) } \\
\text { Anti- } \\
\text { avoidance } \\
\text { strength } \\
\text { (0-6 classif.) }\end{array}$ & $\begin{array}{c}(4 b) \\
\text { Anti- } \\
\text { avoidance } \\
\text { strength } \\
\text { (0-8 classif.) }\end{array}$ \\
\hline Dependent variable & \multicolumn{5}{|c|}{ Markup rate (EBITDA/Turnover) at the corporate group level } \\
\hline Year dummies & yes & yes & yes & yes & yes \\
\hline Country of headquarters dummies & yes & yes & yes & yes & yes \\
\hline Industry dummies & yes & yes & yes & yes & yes \\
\hline MNE group & $\begin{array}{c}0.809^{* * *} \\
{[0.120]}\end{array}$ & & & & \\
\hline Link to no-tax country & & $\begin{array}{l}0.130 \\
{[0.421]}\end{array}$ & & & \\
\hline Number of countries of operation & & & $\begin{array}{c}0.026^{\star *} \\
{[0.010]}\end{array}$ & & \\
\hline Strong anti-avoidance & & & & $\begin{array}{c}-0.563^{* * *} \\
{[0.144]}\end{array}$ & $\begin{array}{c}-0.545^{\star * *} \\
{[0.116]}\end{array}$ \\
\hline Small (<249 employees) - base level & 0 & 0 & 0 & 0 & 0 \\
\hline Large (250-999 employees) & $\begin{array}{c}0.973^{* * *} \\
{[0.121]}\end{array}$ & $\begin{array}{c}1.527^{* * *} \\
{[0.187]}\end{array}$ & $\begin{array}{c}1.498^{* * *} \\
{[0.188]}\end{array}$ & $\begin{array}{c}1.524^{* * *} \\
{[0.187]}\end{array}$ & $\begin{array}{c}1.502^{* * *} \\
{[0.187]}\end{array}$ \\
\hline Very large (1.000-9.999 employees) & $\begin{array}{c}1.303^{* * *} \\
{[0.166]}\end{array}$ & $\begin{array}{c}1.781^{* * *} \\
{[0.220]}\end{array}$ & $\begin{array}{c}1.686^{* * *} \\
{[0.225]}\end{array}$ & $\begin{array}{c}1.761^{* * *} \\
{[0.220]}\end{array}$ & $\begin{array}{c}1.754^{* * *} \\
{[0.220]}\end{array}$ \\
\hline Huge (10.000+ employees) & $\begin{array}{c}1.664^{* * *} \\
{[0.264]}\end{array}$ & $\begin{array}{c}2.031^{* * *} \\
{[0.301]}\end{array}$ & $\begin{array}{c}1.723^{\star \star \star} \\
{[0.337]}\end{array}$ & $\begin{array}{c}1.977^{\star \star \star} \\
{[0.301]}\end{array}$ & $\begin{array}{c}1.967^{\star \star \star} \\
{[0.302]}\end{array}$ \\
\hline Productivity (TFP) & $\begin{array}{c}4.405^{\star \star *} \\
{[0.134]}\end{array}$ & $\begin{array}{c}5.760^{* * *} \\
{[0.185]}\end{array}$ & $\begin{array}{c}5.758^{\star \star \star} \\
{[0.184]}\end{array}$ & $\begin{array}{c}5.740^{\star \star \star} \\
{[0.184]}\end{array}$ & $\begin{array}{c}5.726^{\star \star \star} \\
{[0.184]}\end{array}$ \\
\hline Debt-to-equity ratio & $\begin{array}{c}-0.232^{\star \star *} \\
{[0.028]}\end{array}$ & $\begin{array}{c}-0.280^{\star \star *} \\
{[0.044]}\end{array}$ & $\begin{array}{c}-0.277^{\star \star \star} \\
{[0.044]}\end{array}$ & $\begin{array}{c}-0.274^{\star \star \star} \\
{[0.045]}\end{array}$ & $\begin{array}{c}-0.271^{\star * *} \\
{[0.044]}\end{array}$ \\
\hline Patenting group & $\begin{array}{c}0.758^{\star * *} \\
{[0.149]}\end{array}$ & $\begin{array}{c}0.694^{* * *} \\
{[0.170]}\end{array}$ & $\begin{array}{c}0.663^{* * *} \\
{[0.170]}\end{array}$ & $\begin{array}{c}0.712^{\star * *} \\
{[0.170]}\end{array}$ & $\begin{array}{c}0.720^{\star \star \star} \\
{[0.170]}\end{array}$ \\
\hline Exposure to foreign competition & $\begin{array}{c}0.062^{\star * *} \\
{[0.008]}\end{array}$ & $\begin{array}{c}0.054^{\star \star \star} \\
{[0.009]}\end{array}$ & $\begin{array}{c}0.050^{\star * *} \\
{[0.010]}\end{array}$ & $\begin{array}{c}0.028^{* *} \\
{[0.011]}\end{array}$ & $\begin{array}{c}0.030^{* * *} \\
{[0.011]}\end{array}$ \\
\hline Observations & 17,687 & 9,186 & 9,186 & 9,186 & 9,186 \\
\hline R-squared & 0.235 & 0.287 & 0.288 & 0.288 & 0.289 \\
\hline AdjR2 & 0.233 & 0.282 & 0.282 & 0.283 & 0.284 \\
\hline
\end{tabular}

All regressions are ordinary least squares (OLS). ${ }^{* * *}$ indicates significance at the $1 \%$ level, ${ }^{* *}$ at the $5 \%$ level and ${ }^{*}$ at the $10 \%$ level Robust standard errors are presented under brackets. The sample in column 1 consists of both multinational and non-multinational corporate groups (consolidated financial accounts) over 2000-10. The sample in columns 2 to 4 consists only of multinational groups. Groups with less than 50 employees are excluded. 
Table A1.2 Robustness check: EU countries

\begin{tabular}{|c|c|c|c|c|c|}
\hline & $\begin{array}{c}(1) \\
\text { MNE vs. } \\
\text { domestic }\end{array}$ & $\begin{array}{l}\text { (2) } \\
\text { Link to no-tax } \\
\text { country }\end{array}$ & $\begin{array}{c}(3) \\
\text { MNE } \\
\text { operating in } \\
\text { many } \\
\text { countries }\end{array}$ & $\begin{array}{c}(4 a) \\
\text { Anti- } \\
\text { avoidance } \\
\text { strength } \\
\text { (0-6 classif.) }\end{array}$ & $\begin{array}{c}(4 b) \\
\text { Anti- } \\
\text { avoidance } \\
\text { strength } \\
\text { (0-8 classif.) }\end{array}$ \\
\hline Dependent variable & \multicolumn{5}{|c|}{ Markup rate (EBITDA/Turnover) at the corporate group level } \\
\hline Year dummies & yes & yes & yes & yes & yes \\
\hline Country of headquarters dummies & yes & yes & yes & yes & yes \\
\hline Industry dummies & yes & yes & yes & yes & yes \\
\hline MNE group & $\begin{array}{c}0.685^{\star * *} \\
{[0.084]}\end{array}$ & & & & \\
\hline Link to no-tax country & & $\begin{array}{c}3.858^{\star * *} \\
{[0.754]}\end{array}$ & & & \\
\hline Number of countries of operation & & & $\begin{array}{c}0.056^{* * *} \\
{[0.012]}\end{array}$ & & \\
\hline Strong anti-avoidance & & & & $\begin{array}{l}0.131 \\
{[0.107]}\end{array}$ & $\begin{array}{l}0.040 \\
{[0.095]}\end{array}$ \\
\hline Small (<249 employees) - base level & 0 & 0 & 0 & 0 & 0 \\
\hline Large (250-999 employees) & $\begin{array}{c}0.446^{* * *} \\
{[0.086]}\end{array}$ & $\begin{array}{c}0.529^{* * *} \\
{[0.136]}\end{array}$ & $\begin{array}{c}0.480^{* * *} \\
{[0.137]}\end{array}$ & $\begin{array}{c}0.522^{* * *} \\
{[0.137]}\end{array}$ & $\begin{array}{c}0.534^{* * *} \\
{[0.136]}\end{array}$ \\
\hline Very large (1.000-9.999 employees) & $\begin{array}{c}0.817^{* * *} \\
{[0.134]}\end{array}$ & $\begin{array}{c}0.525^{\star * *} \\
{[0.172]}\end{array}$ & $\begin{array}{c}0.367^{* *} \\
{[0.178]}\end{array}$ & $\begin{array}{c}0.569^{\star * *} \\
{[0.173]}\end{array}$ & $\begin{array}{c}0.583^{* * *} \\
{[0.172]}\end{array}$ \\
\hline Huge (10.000+ employees) & $\begin{array}{c}1.151^{* * *} \\
{[0.306]}\end{array}$ & $\begin{array}{c}0.708^{* *} \\
{[0.352]}\end{array}$ & $\begin{array}{l}0.201 \\
{[0.406]}\end{array}$ & $\begin{array}{c}1.127^{\star \star *} \\
{[0.342]}\end{array}$ & $\begin{array}{c}1.141^{* * *} \\
{[0.342]}\end{array}$ \\
\hline Productivity (TFP) & $\begin{array}{c}1.343^{* * *} \\
{[0.071]}\end{array}$ & $\begin{array}{c}1.654^{* * *} \\
{[0.115]}\end{array}$ & $\begin{array}{c}1.644^{* * *} \\
{[0.116]}\end{array}$ & $\begin{array}{c}1.652^{\star * *} \\
{[0.115]}\end{array}$ & $\begin{array}{c}1.651^{\star \star \star} \\
{[0.115]}\end{array}$ \\
\hline Debt-to-equity ratio & $\begin{array}{c}-0.063^{* * *} \\
{[0.020]}\end{array}$ & $\begin{array}{c}-0.175^{\star * *} \\
{[0.035]}\end{array}$ & $\begin{array}{c}-0.172^{* * *} \\
{[0.035]}\end{array}$ & $\begin{array}{c}-0.174^{\star * *} \\
{[0.034]}\end{array}$ & $\begin{array}{c}-0.174^{* * *} \\
{[0.035]}\end{array}$ \\
\hline Patenting group & $\begin{array}{c}1.768^{* * *} \\
{[0.216]}\end{array}$ & $\begin{array}{c}1.798^{* * *} \\
{[0.239]}\end{array}$ & $\begin{array}{c}1.650^{* * *} \\
{[0.239]}\end{array}$ & $\begin{array}{c}1.872^{\star * *} \\
{[0.238]}\end{array}$ & $\begin{array}{c}1.878^{\star \star *} \\
{[0.237]}\end{array}$ \\
\hline Exposure to foreign competition & $\begin{array}{c}-0.026^{* * *} \\
{[0.006]}\end{array}$ & $\begin{array}{c}-0.023^{* * *} \\
{[0.007]}\end{array}$ & $\begin{array}{c}-0.024^{* * *} \\
{[0.007]}\end{array}$ & $\begin{array}{c}-0.020^{* *} \\
{[0.008]}\end{array}$ & $\begin{array}{c}-0.023^{* * *} \\
{[0.008]}\end{array}$ \\
\hline Observations & 37,369 & 14,156 & 14,156 & 14,156 & 14,156 \\
\hline R-squared & 0.127 & 0.117 & 0.115 & 0.114 & 0.114 \\
\hline AdjR2 & 0.125 & 0.112 & 0.111 & 0.109 & 0.109 \\
\hline
\end{tabular}

All regressions are ordinary least squares (OLS). ${ }^{* *}$ indicates significance at the $1 \%$ level, ${ }^{* *}$ at the $5 \%$ level and ${ }^{*}$ at the $10 \%$ level. Robust standard errors are presented under brackets. The sample in column 1 consists of both multinational and non-multinational corporate groups (consolidated financial accounts) over 2000-10. The sample in columns 2 to 4 consists only of multinational groups. Groups with less than 50 employees are excluded. 
Table A1.3 Robustness check: Continuous firm size variable

\begin{tabular}{|c|c|c|c|c|c|}
\hline & $\begin{array}{c}(1) \\
\text { MNE vs. } \\
\text { domestic }\end{array}$ & $\begin{array}{l}\text { (2) } \\
\text { Link to no-tax } \\
\text { country }\end{array}$ & $\begin{array}{c}(3) \\
\text { MNE } \\
\text { operating in } \\
\text { many } \\
\text { countries }\end{array}$ & $\begin{array}{c}(4 a) \\
\text { Anti- } \\
\text { avoidance } \\
\text { strength } \\
\text { (0-6 classif.) }\end{array}$ & $\begin{array}{c}\text { (4b) } \\
\text { Anti- } \\
\text { avoidance } \\
\text { strength } \\
\text { (0-8 classif.) }\end{array}$ \\
\hline Dependent variable & \multicolumn{5}{|c|}{ Markup rate (EBITDA/Turnover) at the corporate group level } \\
\hline Year dummies & yes & yes & yes & yes & yes \\
\hline Country of headquarters dummies & yes & yes & yes & yes & yes \\
\hline Industry dummies & yes & yes & yes & yes & yes \\
\hline MNE group & $\begin{array}{c}0.906^{* * *} \\
{[0.076]}\end{array}$ & & & & \\
\hline Link to no-tax country & & $\begin{array}{c}1.095^{* * *} \\
{[0.380]}\end{array}$ & & & \\
\hline Number of countries of operation & & & $\begin{array}{l}0.009 \\
{[0.008]}\end{array}$ & & \\
\hline Strong anti-avoidance & & & & $\begin{array}{c}-0.237^{* *} \\
{[0.098]}\end{array}$ & $\begin{array}{c}-0.332^{\star * *} \\
{[0.086]}\end{array}$ \\
\hline Log(employment) & $\begin{array}{c}0.278^{* * *} \\
{[0.029]}\end{array}$ & $\begin{array}{c}0.286^{\star * *} \\
{[0.039]}\end{array}$ & $\begin{array}{c}0.288^{* * *} \\
{[0.044]}\end{array}$ & $\begin{array}{c}0.308^{* * *} \\
{[0.039]}\end{array}$ & $\begin{array}{c}0.305^{\star \star \star} \\
{[0.039]}\end{array}$ \\
\hline Productivity (TFP) & $\begin{array}{c}2.228^{* * *} \\
{[0.067]}\end{array}$ & $\begin{array}{c}2.934^{\star * *} \\
{[0.109]}\end{array}$ & $\begin{array}{c}2.940^{* * *} \\
{[0.109]}\end{array}$ & $\begin{array}{c}2.936^{\star * *} \\
{[0.109]}\end{array}$ & $\begin{array}{c}2.931^{\star * *} \\
{[0.109]}\end{array}$ \\
\hline Debt-to-equity ratio & $\begin{array}{l}0.004 \\
{[0.020]}\end{array}$ & $\begin{array}{c}-0.117^{\star * *} \\
{[0.032]}\end{array}$ & $\begin{array}{c}-0.116^{\star * *} \\
{[0.032]}\end{array}$ & $\begin{array}{c}-0.116^{\star * *} \\
{[0.032]}\end{array}$ & $\begin{array}{c}-0.115^{\star * *} \\
{[0.032]}\end{array}$ \\
\hline Patenting group & $\begin{array}{c}1.594^{\star * *} \\
{[0.134]}\end{array}$ & $\begin{array}{c}1.437^{\star \star \star} \\
{[0.156]}\end{array}$ & $\begin{array}{c}1.437^{\star \star \star} \\
{[0.156]}\end{array}$ & $\begin{array}{c}1.453^{\star * \star} \\
{[0.156]}\end{array}$ & $\begin{array}{c}1.452^{\star \star \star} \\
{[0.156]}\end{array}$ \\
\hline Exposure to foreign competition & $\begin{array}{l}0.003 \\
{[0.005]}\end{array}$ & $\begin{array}{c}-0.008 \\
{[0.006]}\end{array}$ & $\begin{array}{r}-0.007 \\
{[0.006]}\end{array}$ & $\begin{array}{c}-0.017^{\star *} \\
{[0.007]}\end{array}$ & $\begin{array}{c}-0.020^{* * *} \\
{[0.007]}\end{array}$ \\
\hline Observations & 53,250 & 21,566 & 21,566 & 21,566 & 21,566 \\
\hline R-squared & 0.201 & 0.212 & 0.211 & 0.212 & 0.212 \\
\hline AdjR2 & 0.200 & 0.209 & 0.208 & 0.208 & 0.209 \\
\hline
\end{tabular}

All regressions are ordinary least squares (OLS). ${ }^{* * *}$ indicates significance at the $1 \%$ level, ${ }^{* *}$ at the $5 \%$ level and ${ }^{*}$ at the $10 \%$ level. Robust standard errors are presented under brackets. The sample in column 1 consists of both multinational and non-multinational corporate groups (consolidated financial accounts) over 2000-10. The sample in columns 2 to 4 consists only of multinational groups. Groups with less than 50 employees are excluded. 


\section{APPENDIX 2: DETAIL OF THE INDUSTRY CONCENTRATION INDEX}

Table A2.1 Industry concentration index

Combined market share of top-10 firms (by turnover) divided by market share of top-100 firms, 2009

\begin{tabular}{|c|c|c|c|c|c|c|c|c|c|c|c|c|c|c|c|c|c|c|c|c|c|c|c|c|c|c|c|c|c|}
\hline Country & 01_05 & 10_14 & 15_16 & 17_18 & 19 & 20 & 21_22 & 24 & 25 & 26 & 27_28 & 29 & 30_33 & 34_35 & 36_37 & 40_41 & 45 & 50 & 51 & 52 & 55 & 60 & 61 & 63 & 64 & $65 \_67$ & 70 & 71_74 & Average \\
\hline BE & 0.49 & - & 0.32 & 0.51 & - & 0.45 & 0.52 & 0.59 & 0.52 & 0.45 & 0.43 & 0.70 & 0.45 & 0.86 & 0.28 & 0.72 & 0.43 & 0.23 & 0.38 & 0.60 & 0.40 & 0.59 & - & 0.42 & 0.86 & 0.72 & 0.26 & 0.28 & 0.50 \\
\hline$B R$ & - & - & 0.66 & - & - & - & 0.56 & 0.50 & 0.37 & - & 0.65 & 0.48 & 0.43 & 0.75 & - & - & 0.65 & - & 0.38 & 0.62 & - & 0.49 & - & 0.61 & - & 0.58 & - & 0.54 & 0.55 \\
\hline $\mathrm{CN}$ & - & - & 0.50 & 0.51 & 0.40 & - & 0.55 & 0.35 & 0.54 & - & 0.37 & 0.34 & 0.41 & 0.60 & 0.41 & - & - & 0.83 & 0.39 & 0.53 & - & - & - & - & - & 0.58 & - & 0.71 & 0.50 \\
\hline CO & 0.35 & 0.73 & 0.56 & 0.54 & - & - & 0.56 & 0.55 & 0.53 & 0.70 & 0.67 & 0.64 & 0.69 & - & 0.52 & 0.63 & 0.43 & 0.89 & 0.39 & 0.66 & 0.45 & 0.64 & - & 0.44 & 0.98 & 0.39 & 0.37 & 0.55 & 0.58 \\
\hline CZ & 0.48 & 0.91 & 0.37 & 0.48 & - & 0.64 & 0.47 & 0.54 & 0.56 & 0.37 & 0.36 & 0.37 & 0.54 & 0.69 & 0.50 & 0.77 & 0.56 & 0.59 & 0.32 & 0.65 & 0.45 & 0.56 & - & 0.46 & 0.93 & 0.72 & 0.60 & 0.29 & 0.55 \\
\hline DE & 0.33 & 0.57 & 0.39 & 0.58 & 0.60 & 0.48 & 0.42 & 0.62 & 0.46 & 0.41 & 0.43 & 0.35 & 0.33 & 0.52 & 0.35 & 0.49 & 0.35 & 0.26 & 0.40 & 0.30 & 0.45 & 0.75 & 0.50 & 0.49 & 0.96 & 0.37 & 0.27 & 0.40 & 0.46 \\
\hline DK & 0.71 & - & 0.68 & - & - & - & 0.63 & - & - & - & 0.67 & 0.72 & 0.67 & - & - & 0.66 & 0.44 & 0.47 & 0.44 & 0.78 & 0.68 & 0.69 & 0.97 & 0.62 & - & 0.57 & 0.50 & 0.46 & 0.63 \\
\hline EE & 0.31 & 0.65 & 0.45 & 0.56 & - & 0.46 & 0.53 & - & 0.49 & 0.68 & 0.46 & 0.39 & 0.60 & 0.69 & 0.42 & 0.88 & 0.45 & 0.51 & 0.43 & 0.56 & 0.39 & 0.43 & - & 0.54 & 0.92 & 0.77 & 0.26 & 0.42 & 0.53 \\
\hline ES & 0.36 & 0.67 & 0.37 & 0.50 & 0.37 & 0.39 & 0.40 & 0.37 & 0.55 & 0.34 & 0.38 & 0.56 & 0.39 & 0.61 & 0.35 & 0.72 & 0.56 & 0.49 & 0.41 & 0.80 & 0.49 & 0.48 & 0.46 & 0.50 & 0.87 & 0.45 & 0.40 & 0.43 & 0.49 \\
\hline $\mathrm{Fl}$ & 0.83 & 0.77 & 0.50 & 0.58 & - & 0.45 & 0.71 & 0.69 & 0.46 & 0.61 & 0.70 & 0.55 & 0.83 & 0.54 & 0.61 & 0.52 & 0.56 & 0.37 & 0.46 & 0.47 & 0.62 & 0.55 & 0.87 & 0.47 & 0.90 & 0.72 & 0.42 & 0.59 & 0.60 \\
\hline FR & 0.34 & 0.40 & 0.36 & 0.42 & 0.56 & 0.34 & 0.34 & 0.46 & 0.42 & 0.56 & 0.51 & 0.38 & 0.53 & 0.80 & 0.41 & 0.91 & 0.36 & 0.52 & 0.40 & 0.63 & 0.60 & 0.44 & 0.67 & 0.49 & 0.74 & 0.52 & 0.41 & 0.45 & 0.50 \\
\hline GB & 0.34 & 0.65 & 0.40 & 0.43 & - & 0.43 & 0.36 & 0.43 & 0.38 & 0.51 & 0.35 & 0.64 & 0.54 & 0.71 & 0.26 & 0.69 & 0.38 & 0.35 & 0.72 & 0.67 & 0.49 & 0.59 & 0.78 & 0.50 & 0.76 & 0.49 & 0.42 & 0.48 & 0.51 \\
\hline GR & 0.50 & 0.61 & 0.39 & 0.29 & . & 0.56 & 0.35 & 0.52 & 0.44 & 0.55 & 0.58 & 0.59 & 0.62 & 0.73 & 0.47 & 0.97 & 0.56 & 0.42 & 0.33 & 0.65 & 0.29 & 0.44 & - & 0.31 & . & 0.85 & 0.37 & 0.34 & 0.51 \\
\hline HU & 0.31 & 0.61 & 0.40 & 0.38 & 0.75 & 0.54 & 0.40 & 0.80 & 0.46 & 0.44 & 0.53 & 0.56 & 0.67 & 0.75 & 0.44 & 0.55 & 0.38 & 0.40 & 0.43 & 0.67 & 0.50 & 0.67 & - & 0.58 & 0.91 & 0.79 & 0.30 & 0.36 & 0.54 \\
\hline $\mathbb{N}$ & 0.75 & - & 0.46 & 0.38 & - & - & 0.65 & 0.38 & 0.47 & - & 0.52 & 0.58 & 0.45 & 0.63 & - & 0.60 & 0.46 & - & 0.51 & 0.81 & - & - & - & - & - & 0.59 & - & 0.54 & 0.55 \\
\hline IS & 0.77 & - & 0.66 & - & - & - & 0.80 & - & - & - & 0.98 & - & - & - & - & - & 0.39 & 0.76 & 0.81 & 0.92 & 0.39 & 0.41 & - & - & - & - & 0.75 & 0.68 & 0.69 \\
\hline IT & 0.32 & 0.44 & 0.35 & 0.38 & 0.33 & 0.30 & 0.42 & 0.40 & 0.28 & 0.33 & 0.37 & 0.32 & 0.43 & 0.69 & 0.32 & 0.67 & 0.48 & 0.21 & 0.36 & 0.47 & 0.52 & 0.61 & 0.78 & 0.56 & 0.90 & 0.46 & 0.62 & 0.39 & 0.45 \\
\hline JP & 0.44 & 0.63 & 0.41 & 0.54 & - & 0.44 & 0.53 & 0.38 & 0.48 & 0.46 & 0.44 & 0.68 & 0.61 & 0.69 & 0.41 & 0.89 & 0.34 & 0.32 & 0.39 & 0.29 & 0.34 & 0.67 & 0.43 & 0.43 & 0.68 & 0.66 & 0.46 & 0.37 & 0.50 \\
\hline KR & 0.37 & 0.49 & 0.50 & 0.50 & 0.58 & 0.41 & 0.48 & 0.45 & 0.54 & 0.71 & 0.33 & 0.57 & 0.86 & 0.79 & 0.45 & 0.93 & 0.64 & 0.37 & 0.37 & 0.57 & 0.59 & 0.65 & 0.58 & 0.49 & 0.71 & 0.43 & 0.78 & 0.48 & 0.56 \\
\hline NO & 0.65 & 0.85 & 0.57 & 0.47 & - & 0.41 & 0.53 & 0.65 & 0.49 & 0.55 & 0.55 & 0.70 & 0.64 & 0.62 & 0.45 & 0.44 & 0.49 & 0.28 & 0.38 & 0.43 & 0.46 & 0.50 & 0.41 & 0.55 & 0.87 & 0.68 & 0.28 & 0.40 & 0.53 \\
\hline PL & 0.72 & 0.81 & 0.35 & 0.42 & 0.58 & 0.54 & 0.49 & 0.48 & 0.40 & 0.37 & 0.36 & 0.49 & 0.50 & 0.67 & 0.39 & 0.58 & 0.43 & 0.52 & 0.38 & 0.65 & 0.52 & 0.59 & - & 0.43 & 0.92 & 0.55 & 0.39 & 0.29 & 0.51 \\
\hline PT & 0.35 & 0.61 & 0.42 & 0.26 & 0.31 & 0.54 & 0.57 & 0.38 & 0.52 & 0.56 & 0.43 & 0.43 & 0.69 & 0.69 & 0.32 & 0.72 & 0.50 & 0.39 & 0.33 & 0.68 & 0.44 & 0.45 & 0.74 & 0.51 & 0.95 & 0.73 & 0.32 & 0.38 & 0.51 \\
\hline RU & 0.25 & 0.59 & 0.41 & 0.33 & 0.47 & 0.35 & 0.49 & 0.41 & 0.38 & 0.35 & 0.70 & 0.48 & 0.52 & 0.52 & 0.42 & 0.45 & 0.30 & 0.37 & 0.26 & 0.49 & 0.49 & 0.55 & 0.42 & 0.46 & 0.82 & 0.72 & 0.41 & 0.32 & 0.45 \\
\hline SE & 0.68 & 0.83 & 0.53 & 0.45 & - & 0.46 & 0.52 & 0.78 & 0.41 & 0.54 & 0.45 & 0.53 & 0.84 & 0.64 & 0.34 & 0.57 & 0.69 & 0.49 & 0.37 & 0.61 & 0.52 & 0.55 & 0.54 & 0.49 & 0.91 & 0.74 & 0.28 & 0.51 & 0.57 \\
\hline SI & - & - & 0.58 & 0.64 & . & 0.59 & 0.65 & - & 0.61 & - & 0.54 & 0.57 & 0.59 & - & 0.52 & - & 0.51 & 0.49 & 0.44 & 0.78 & 0.69 & 0.58 & - & 0.81 & - & - & - & 0.34 & 0.58 \\
\hline SK & 0.34 & - & 0.57 & - & - & 0.62 & 0.79 & - & 0.63 & - & 0.86 & 0.66 & 0.88 & - & 0.69 & . & 0.65 & 0.39 & 0.45 & 0.70 & 0.51 & 0.30 & . & 0.52 & . & . & 0.46 & 0.36 & 0.58 \\
\hline TR & - & - & 0.62 & 0.38 & - & - & 0.60 & 0.65 & 0.65 & - & 0.55 & 0.53 & 0.63 & - & - & - & 0.51 & 0.74 & 0.52 & 0.80 & - & - & - & 0.64 & - & - & - & 0.86 & 0.62 \\
\hline US & 0.42 & 0.55 & 0.50 & 0.39 & - & 0.47 & 0.48 & 0.45 & 0.62 & - & 0.35 & 0.50 & 0.53 & 0.63 & 0.61 & 0.52 & 0.32 & 0.29 & 0.32 & 0.44 & 0.37 & 0.48 & - & 0.52 & 0.56 & 0.36 & 0.61 & 0.81 & 0.48 \\
\hline Average & 0.48 & 0.65 & 0.48 & 0.46 & 0.50 & 0.47 & 0.53 & 0.51 & 0.49 & 0.50 & 0.52 & 0.53 & 0.59 & 0.67 & 0.43 & 0.68 & 0.48 & 0.46 & 0.42 & 0.62 & 0.49 & 0.55 & 0.63 & 0.51 & 0.85 & 0.60 & 0.43 & 0.47 & 0.54 \\
\hline
\end{tabular}

Note: Missing values correspond to industries with less than 100 observations of unconsolidated firm accounts in the ORBIS database. Countries with less than 10 industries with nonmissing data are excluded.

Source: OECD calculations based on ORBIS database. 